\title{
Early Eocene carbon isotope excursions in a lignite bearing succession at the southern edge of the proto-North Sea (Schöningen, Germany)
}

\author{
Olaf K. Lenz ${ }^{1,2}$, Mara Montag ${ }^{2}$, Volker Wilde ${ }^{1}$, Katharina Methner ${ }^{3,5}$, Walter Riegel ${ }^{1}$, Andreas \\ Mulch ${ }^{3,4}$ \\ ${ }^{1}$ Senckenberg Research Institute and Natural History Museum Frankfurt, 60325 Frankfurt am Main, Germany. \\ ${ }^{2}$ Institute of Applied Geosciences, Technical University Darmstadt, 64287 Darmstadt, Germany. \\ ${ }^{3}$ Senckenberg Biodiversity and Climate Research Centre (SBiK-F), Senckenberganlage 25, 60325 Frankfurt am \\ Main, Germany. \\ ${ }^{4}$ Institute of Geosciences, Goethe University Frankfurt, 60438 Frankfurt am Main, Germany. \\ ${ }^{5}$ Department of Earth System Science, Department of Geological Sciences, Stanford University, USA.
}

\section{Content:}

\section{$\underline{\text { S1 Lithologic description of sampled sections }}$}

Fig. S1 Lithological logs of the sampled sections.

\section{S2 Panels}

Fig. S2 Apectodinium species (SEM pictures) from interbeds of the lower part of the Schöningen Formation.

Fig. S3 Selected dinoflagellate cysts (SEM pictures) from Interbed 2 of the Schöningen Formation.

Fig. S4 Selected dinoflagellate cysts (LM pictures) from Interbed 3 of the Schöningen Formation.

Fig. S5 Comparison of $\delta^{13} \mathrm{C}$ data for the Paleocene-Eocene Thermal Maximum (PETM) in continental/marginal marine records.

\section{S3 Data tables}

Table S1 Total organic carbon concentration (\%TOC) and carbon isotope of bulk organics $\left(\delta^{13} \mathrm{C}_{\mathrm{TOC}}\right)$ data

Table S2 Palynological data of the Main Seam (raw data).

Table S3 Palynological data of the Main Seam (percentage data). 


\section{SI1 Lithologic description of sampled sections}

Detailed descriptions of sections "Schoe XLIX", "Schoe IX", "Schoe V", "Schoe VI", "Schoe XXV", "Schoe XIII" and "Schoe I".

\section{Abbreviations for lignite lithotypes:}

Macropetrographic lithotype classification adapted from Vogt (1981)

$\mathrm{ML}=$ matrix dominated lithotype

$\mathrm{TL}=$ tissue dominated lithotype

$\mathrm{TML}=$ mixed tissue/matrix lithotype

\section{Section/horizon (thickness) Description}

Schoe $1 / 80 \quad(28 \mathrm{~cm})$ Dark clayey silt to silty clay, reddish when fresh, bedding recognizable by light-colored streaks, rooting.

Schoe 1/79 $(17 \mathrm{~cm})$ Dark sandy clay, sand content decreasing upward, some root structures, no bedding.

Schoe I/78 $\quad(20 \mathrm{~cm})$ Medium brown sand, densely bioturbated, scattered rooting, dark clayey lenses.

Schoe $1 / 77 \quad(14 \mathrm{~cm})$ Dark silty clay, no bedding.

Schoe $1 / 76 \quad(40 \mathrm{~cm})$ Dark clayey silt with fine light silt lenses and flasers.

Base of Interbed 7

\section{Top of Seam 6}

Schoe l/75 $(52 \mathrm{~cm})$ Dark matrix lignite lithotype to layered lithotype, well bedded, alternation between leafy and charcoal layers, charcoal dominating.

Schoe $1 / 74 \quad(12-20 \mathrm{~cm})$ Light-colored lignite lithotype, scattered light-colored tissue and gelified roots.

Schoe I/73 $(96 \mathrm{~cm})$ Dark tissue lignite lithotype to layered lithotype, well bedded, alternation between leafy and charcoal layers, regular with pyrite concretions, upper part more massive and reddish when fresh.

Schoe I/72 (36 cm) Dark mixed tissue/matrix lignite lithotype with scattered charcoal layers, xylitic, with some larger xylites and tree stumps.

Schoe I/71 $(65 \mathrm{~cm})$ Matrix to mixed tissue/matrix lignite lithotype, xylite with gelified xylites and roots, some tree stumps, distinctly reddish when fresh, resin particles.

\section{Base of Seam 6}

\section{Top of Interbed 6}

Schoe $1 / 70 \quad(3-5 \mathrm{~cm})$ Brown clayey silt, flat-lying light-colored bioturbation lenticular in cross section, thick horizontal root branches.

Schoe I/69 $\quad(3-5 \mathrm{~cm})$ Dark clay, dense horizontal rooting, no bedding.

Schoe I/68 $\quad(32 \mathrm{~cm})$ Dark clayey silt, laminated below, increasingly rooted upward.

Schoe I/67 $(4-6 \mathrm{~cm})$ Coarse to medium grained light-colored sand, erosive lower contact, irregular bedding below, rooting above.

Schoe 1/66 $\quad(2-7 \mathrm{~cm})$ Dark silty clay to clayey silt, locally thin-bedded, rooted, sand filled bioturbation tubes, upper contact eroded.

Schoe I/65 $(24 \mathrm{~cm})$ Fine to medium sand with small scale cross-bedding and some dark clay/silt layers, thin bioturbation tubes, fine rooting.

Schoe I/64 $(8 \mathrm{~cm})$ Light-colored medium sand, in part (ripple?) cross-bedded, thick $(1 \mathrm{~cm})$ bioturbation tubes with dark filling parallel to bedding, fine rooting.

Schoe I/63 $(60 \mathrm{~cm})$ Silty fine sand, mottled, densely bioturbated, upward light-colored and no bioturbation.

Schoe I/62 (21 cm) Dark clayey silt to fine sand, clay content decreasing upward, small scale (ripple?) cross-bedding, numerous bioturbation tubes filled with dark sand. 

diameter) filled with dark fine sand.

Schoe I/60 (49 cm) Dark stiff silty clay with reddish-brown lenses and flasers of clayey silt, small scale cross-bedding (ripples?), no bioturbation.

Schoe $1 / 59 \quad(18 \mathrm{~cm})$ Brown silty clay with fine silt lenses and laminae, upward lightening, bioturbation.

Schoe I/58 (41 cm) Dark clay with lenses and flasers of fine sand and silt internally laminated and in part graded, distinct bioturbation.

Schoe I/57 $(70 \mathrm{~cm})$ Lenses and flasers of light-colored fine sand in dark clay with randomly distributed bioturbation tubes.

Schoe $1 / 56 \quad(6 \mathrm{~cm})$ Dark silty clay with silt lenses and laminae, in part with cross-bedding and bioturbation tubes filled with light-colored sand.

Schoe $1 / 55 \quad(7 \mathrm{~cm})$ Light beige clayey silt, \pm parallel bedded with pyrite concretions and bioturbation tubes.

Schoe I/54 (12 cm) Slightly clayey silt with desiccation structures, originally laminated.

Schoe I/53 $\quad(60 \mathrm{~cm})$ Light beige clayey silt with few bioturbation tubes, scattered xylites.

Schoe I/52 (55 cm) Light brown clayey silt with lenses and streaks of silt, clay content decreasing upward, hollow trunk $20 \mathrm{~cm}$ above base.

Schoe I/51 (42 cm) Clayey silt with thick lenses of silt near base, decreasing in size upward.

Schoe $\mathrm{I} / 50 \quad(10 \mathrm{~cm})$ Reddish brown clayey fine sand.

Schoe $1 / 49$

$(15 \mathrm{~cm})$ As bed Schoe $\mathrm{l} / 48$ but beige-brown, somewhat darker and more silty at top.

Schoe $1 / 48$

Schoe $1 / 47$

$(36 \mathrm{~cm})$ Brown-grey silty clay with fine streaks and lenses of silt.

$(12 \mathrm{~cm})$ Black carbonaceous clay, reddish when fresh, upper contact bioturbated, lower contact transitional.

Schoe I/46 $\quad(47 \mathrm{~cm})$ Dark to black silty clay, near base bedding indicated, upward gelified root traces.

Schoe I/45 (33 cm) Dark brown silty clay, mainly massive, cup-shaped fracturing.

Schoe I/44

$(28 \mathrm{~cm})$ Silty clay, more silty below, more homogeneous above, well-bedded, darker than bed Schoe $1 / 43$.

Schoe I/43 (26 cm) Dark silty clay with light-colored silt laminae and lenses, cross-bedded, no bioturbation.

Schoe I/42 (33 cm) Dark brown stiff clay, slightly silty, with thin well- to cross-bedded silt layers, silt content increasing upward.

Schoe I/41 (12 cm) Dark silty clay with fine silt lenses and streaks.

Schoe $1 / 40 \quad(10 \mathrm{~cm})$ As bed 39 but more clayey, darker, with fine lenses and flasers, less bioturbation, upper contact eroded.

Schoe $1 / 39 \quad(12 \mathrm{~cm})$ Dark clayey silt alternating with light-colored silt in coarse lenses and flasers, distinct bioturbation, cross-bedding in some lenses.

Schoe I/38 $(23 \mathrm{~cm})$ Dark clayey silt alternating with light-colored silt in fine lenses and flasers, densely bioturbated with fine tubes.

Schoe I/37 (42 cm) Clayey silt alternating with lenses and thin layers of silt, in middle coarse silt lenses with cross-bedding, below and above dark with fine light-colored lenses and streaks, near top bioturbation.

Schoe $1 / 36 \quad(0-2 \mathrm{~cm})$ Light brown medium to coarse sand, in channels up to $12 \mathrm{~cm}$ thick, cross-bedded.

Schoe $1 / 35$ $(6 \mathrm{~cm})$ Dark brown clayey silt locally silt streak, but \pm unbedded.

Schoe I/34 $(14 \mathrm{~cm})$ Dark matrix lignite lithotype, well-bedded by fine silt laminae, reddish when fresh.

Schoe I/33

Schoe I/32 $(18 \mathrm{~cm})$ Clayey silt with lenses, flasers and streaks of light-colored silt, light colored bioturbation tubes, near base flat lying xylite.

$(28 \mathrm{~cm})$ Dark brown clayey silt with beige silt lenses and flasers mainly in lower part, slightly bioturbated.

Schoe I/31 $(24 \mathrm{~cm})$ Dark brown clayey silt, thin- to flaser-bedded.

Schoe $\mathrm{I} / 30 \quad(36 \mathrm{~cm})$ Dark brown clay, lighter colored and more silty below, graded bedding. 

xylite.

Schoe $\mathrm{I} / 28 \quad(5-7 \mathrm{~cm})$ Beige-brown sand, irregular ripple bedding.

Schoe $1 / 27 \quad(15 \mathrm{~cm})$ Dark brown clay, bedding indicated.

Schoe $1 / 26 \quad(33 \mathrm{~cm})$ Beige-brown clayey silt with white lenses and flasers of fine sand, more common upward, transition of flaser- to ripple-bedding.

Schoe I/25 (37 cm) Beige-brown clayey silt, below darker with light-colored silt flasers, upward lighter with fine ripple-bedding.

Schoe $1 / 24 \quad(51 \mathrm{~cm})$ Beige-brown clayey silt, in middle clay and silt in distinct layers.

Schoe $\mathrm{I} / 23 \quad(11 \mathrm{~cm})$ Brown compact clayey silt, largely unbedded, mottled.

Schoe $1 / 22 \quad(10 \mathrm{~cm})$ Dark brown silty clay, fine bedding with silt laminae.

Schoe l/21 (20 cm) Dark silty clay with numerous lenses and flasers of silt and fine sand, bioturbation parallel to bedding, lower contact with breached surface of Seam 5 .

\section{Base of Interbed 6}

\section{Top of Seam 5}

Schoe I/20 (50 cm) Mixed tissue/matrix to tissue lignite lithotype, reddish when fresh, charcoal on bedding plains.

Schoe I/19 $\quad(7 \mathrm{~cm})$ Dark carbonaceous sand with gelified root traces, no bedding.

Schoe I/18 $\quad(6 \mathrm{~cm})$ Dark clayey silt with fine sand, gelified root traces, some silt flasers.

Schoe $1 / 17 \quad(4 \mathrm{~cm})$ Black gelified matrix lignite lithotype.

Schoe I/16 (23 cm) Dark brown matrix lignite lithotype, reddish when fresh, scattered resin particles and kaolinite filled bioturbation tubes, some xylites.

Schoe I/15 (11-13 cm) Carbonaceous clay with gelified root traces, some sand-filled bioturbation tubes, silt dispersed and in silt flasers.

Base of Seam 5

\section{Top of Interbed 5}

Schoe I/14 (75 cm) Fine sand coarsening upward with organic flasers and few dark clayey layers, ooting from middle of bed upward, small scale ripple bedding.

Schoe I/13 (90 cm) Fine sand/silt, sand content increasing upward, below light brown with organic flasers and laminae, small scale ripple bedding, upward light beige, fewer organic flasers and bedding features.

Schoe I/12 $(7 \mathrm{~cm})$ Transitional to bed Schoe I/13: light grayish brown, thin bedded, in lower part silt laminae and organic layers, scattered bioturbation tubes.

Schoe I/11 $(18 \mathrm{~cm})$ Medium gray brownish silt with numerous light-colored sand-filled bioturbation tubes, upward lighter colored, largely unbedded.

Schoe I/10 (37 cm) Highly clayey silt, darker than bed 9, with numerous silt laminae and flasers and bioturbation tubes filled with light-colored sand, both mainly in upper part.

Schoe I/9 (24 cm) Dark clayey silt with fine sand, some silt flasers and light-colored filled bioturbation tubes, unbedded, massive.

Schoe I/8 (22 cm) Dark clayey silt, silt in streaks and lenses and in bioturbation intense, tubes parallel to bedding, no vertical tubes!

Schoe $1 / 7 \quad(54 \mathrm{~cm})$ Dark sand, unbedded, with dense bioturbation, tubes dark with light-colored sandy core.

Schoe I/6 (25 cm) Fine sandy clayey silt, flaser-bedded, dense bioturbation with tubes filled with lightcolored sand, irregular top contact.

Schoe $1 / 5 \quad(23 \mathrm{~cm})$ Dark sand with thin coaly streaks, no bedding, dense bioturbation with tubes filled with light-colored sand.

Schoe $1 / 4 \quad(27 \mathrm{~cm})$ Reddish brown clayey silt darkening upon aerial exposure, compact, internally flaserto lenticular bedding, upward increasing number of sand-filled bioturbation tubes. 
Schoe I/3 $\quad(23 \mathrm{~cm})$ Clayey silt with distinct silt streaks especially in lower part, upper part lighter colored

Schoe $\mathrm{l} / 2 \quad(5 \mathrm{~cm})$ Dark silty clay with very fine silt streaks

Schoe I/1 (>15 cm) Open end: dark gelified matrix lignite lithotype, in part xylitic, numerous silt streaks and pockets, silt in breaches of seam top and bioturbation tubes.

Schoe XIII/37 (10 cm) Dark carbonaceous clay, rooted with numerous slickensides and thin light-colored clayey flasers, largely without bedding, tree stumps near base.

\section{Base of Interbed 5}

\section{Top of Seam 4}

Schoe XIII/36 (4-5 cm) Medium brown matrix lignite lithotype with some light-colored tissue, kaolinite-filled root traces, frequent slickensides, xylites (tree stumps) at top.

Schoe XIII/35 $(14 \mathrm{~cm})$ Dark matrix lignite lithotype with light-colored tissue, with gelified and frequently kaolinite-filled root traces.

Schoe XIII/34 (12 cm) Dark matrix to mixed tissue/matrix lignite lithotype with light-colored tissue an xylites, gelified an kaolinite-filled root traces.

Schoe XIII/33 $(7 \mathrm{~cm})$ Beige to dark brown clay, densely rooted with numerous flat xylitic roots.

\section{Base of Seam 4}

\section{Top of Interbed 4}

Schoe XIII/32

Schoe XIII/31

Schoe $X I I I / 30$

Schoe XIII/29

Schoe XIII/28

Schoe XIII/27

Schoe XIII/26

Schoe XIII/25

Schoe XIII/24

Schoe XIII/23

Schoe XIII/22

Schoe XIII/21

Schoe $X I I I / 20$

Schoe XIII/19

Schoe XIII/18

Schoe XIII/17
$(18 \mathrm{~cm})$ Beige silty clay, densely rooted, unbedded, scattered resin particles.

$(17 \mathrm{~cm})$ Beige silty clay, towards top increasingly coaly particles indicating thin bedding, organically preserved hollow axes crossing bedding.

$(20 \mathrm{~cm})$ Dark silty clay with irregular to wavy light-colored lenses and layers of silt, rooted with thick coaly root traces, horizontal embedded xylite in middle.

$(480 \mathrm{~cm})$ As bed Schoe XIII/28: Greenish when fresh, bioturbation tubes up to $2 \mathrm{~cm}$ in diameter in middle part, at $240 \mathrm{~cm}$ from base pyrite concretions, clay content increasing toward top. Boundary with bed Schoe XIII/29 mainly drawn on the basis of greater water content.

$(220 \mathrm{~cm})$ Greyish brown mixture of clay, silt and sand with high proportion of mica, light grey upon drying, totally bioturbated with tubes of $1 \mathrm{~cm}$ in diameter, scattered pyrite nodules ("Glimmersand" in literature).

$(165 \mathrm{~cm})$ Medium to dark grey silty clay to clayey silt, silt content increasing toward top, thinbedded by numerous thin light-colored silt streaks, scattered thicker silt layers and lenses, fine horizontal bioturbation tubes partly pyritized, abundant mica, forams in middle part(?). $(28 \mathrm{~cm})$ Dark very silty clay, massive, unbedded, no bioturbation.

$(52 \mathrm{~cm}$ ) Similar to bed 20: alternation of brown silty clay and light-colored silt layers and lenses, in part cross-bedded, fine bioturbation $(<1 \mathrm{~mm})$, top boundary uneven but sharp. $(32 \mathrm{~cm})$ Dark clay, massive with very scattered light colored silt streaks, mica present. $(150 \mathrm{~cm})$ Dark silty clay with light-colored silt lenses and layers, thin-bedded, silt layers particularly abundant in middle part with fine bioturbation.

(35 cm) As bed Schoe XIII/20, but with thin vertical bioturbation tubes, cross-bedding in thicker silt layer, no pyrite.

$(9 \mathrm{~cm})$ Dark silty clay, well bedded by light-colored silt lamina, pyrite on bedding planes, forams?

$(25 \mathrm{~cm})$ Alternation of more clayey and more silty layers about $1 \mathrm{~cm}$ thick, silt content and silt layers increasing toward top, bioturbation random in direction, pyrite concretions.

$(30 \mathrm{~cm})$ As bed Schoe XIII/17 but silt content somewhat higher, bioturbation tubes in part filled with pyrite.

$(14 \mathrm{~cm})$ Coarse sand cross-bedded with finely bedded light-colored silt and clay flasers. $(69 \mathrm{~cm})$ Alternation of dark clayey and light-colored silt layers frequently divided into lenses by dense bioturbation. 
Schoe XIII/16 $(48 \mathrm{~cm})$ Similar to bed Schoe XIII/15: light grey fine sand with secondary discoloration streaks, fine bedding in lower $5 \mathrm{~cm}$, bioturbation tubes less dense but $1 \mathrm{~cm}$ in diameter, in part thin netted bioturbation.

Schoe XIII/15 (17 cm) Light grey fine sand with dark discoloration streaks and mottling, densely bioturbated by light-colored tubes $2 \mathrm{~mm}$ in width, no bedding, sharp boundary at top.

Schoe XIII/14 (42 cm) Medium brown clayey/silty fine sand at base to fine sand at top, unbedded, cryptic bedding in lower third, fine root traces, bioturbation in upper third, coal clasts at top, scattered pyrite concretions.

Schoe XIII/13 $(32 \mathrm{~cm})$ 4-fold coarsening upward alternation of well-bedded dark clayey and light-colored silt layers with beige unbedded fine sand, regularly with randomly oriented bioturbation tubes (2$3 \mathrm{~mm}$ in diameter).

Schoe XIII/12 $(22 \mathrm{~cm})$ Reddish silt to fine sand, unbedded, with dark coaly streaks (root traces!) and scattered grains of coarse sand, pyrite concretions.

Schoe XIII/11 $(1 \mathrm{~cm})$ Coarse sand, in part mixed with underlying bed Schoe XIII/10 by bioturbation.

Schoe XIII/10 (41 cm) Medium brown clayey silt with minute cross-bedding, bioturbation increasing toward top, coaly detritus in layers.

Schoe XIII/9 $\quad(150 \mathrm{~cm})$ Dark slightly silty clay, occasionally silt layers with cross-bedding, five-fold fining upward cycles each with ripple- to cross-bedding at base.

Schoe XIII/8 $\quad(140 \mathrm{~cm})$ Medium light-colored silty clay, in part reddish, distinct but irregular fine bedding, locally with light-colored silt lamina and fine ripples, generally disrupted by fine randomly occurring bioturbation tubes up to $2 \mathrm{~mm}$ in diameter, one layer (at 1.00 to $1,10 \mathrm{~m}$ from base) more clayey, layer at 1.10 to $1.18 \mathrm{~m}$ fine sand, top boundary sharp.

Schoe XIII/7 (24 cm) Clayey silt to silty clay, silt content decreasing toward top bedded by light-colored silt layer in lower part, distinct fining upward tendency, bioturbation rare.

Schoe XIII/6 $\quad(5 \mathrm{~cm})$ Medium light-colored lightly greenish fine sandy silt, highly bioturbated, some \pm vertical tubes $(0.5 \mathrm{~cm})$ extending into coal below.

Schoe XXV/39 (19 cm) Dark clayey silt with fine sand, well bedded by very thin light-colored silt/fine sand laminae, regular light-colored bioturbation tubes $2-5 \mathrm{~mm}$ in diameter.

Schoe XXV/38 $(10 \mathrm{~cm})$ Gray silt to light-colored fine sand, thin bedding by interspersed light-colored layers in part with cross-bedding, pyritized bioturbation tubes, xylite at base, coarse sand in shallow channels.

\section{Base of Interbed 4}

\section{Top of Seam 3}

Schoe XXV/37 $(31 \mathrm{~cm})$ As bed 36, but lignite completely disrupted by an irregular network of layers, veins and tubes filled with poorly sorted medium to coarse sand, gelified root traces not as common as in bed Schoe XXV/36.

Schoe XXV/36 $(37 \mathrm{~cm})$ Medium brown xylitic matrix lignite lithotype, gelified root traces and resin particles common, thin silt layer near base.

Schoe XXV/35 (35 cm) Medium to light brown matrix lignite lithotype with silt lenses near base, xylites and gelified root traces.

\section{Base of Seam 3}

\section{Top of Interbed 3}

Schoe XXV/34 $(38 \mathrm{~cm})$ Light gray brown clayey silt, upward lighter colored and more silty, intensely rooted with thick gelified root branches, no bedding, thickness decreasing toward SE.

Schoe XXV/33 (42 cm) Dark silty clay to clayey silt bedded by organic rich silty layers, but generally massive, upward increasingly rooted, near top thick root branches and slickensides thickness decreasing toward SE. 
Schoe XXV/32 $(23 \mathrm{~cm})$ Dark silty clay with layers and flasers of light-colored silt and fine sand particular in middle of bed, layers with small scale ripple bedding, thin continuous layer of silt and fine sand at top, equivalent to bed Schoe XXV/6 below.

Schoe XXV/31 $(45 \mathrm{~cm})$ Dark silty clay to clayey silt with silt streaks, fine near base, upward increasing in number and thickness, bioturbation rare but more common upward, pyrite finely dispersed, thickness of bed decreasing toward SE, equivalent to bed Schoe XXV/7 below.

Schoe XXV/30 $(28 \mathrm{~cm})$ Dark brown silty clay with fine sand and mica, massive, no bedding, some bioturbation tubes $(5 \mathrm{~mm})$ filled with fine sand, bed thickening toward SE, equivalent to bed Schoe XXV/8 below.

Schoe XXV/29 (24 cm) Dark carbonaceous clayey fine sand, fining upward, distinctly brown when fresh, no rooting.

Schoe XXV/28 (96 cm) Dark carbonaceous fine to medium sand, in upper third fine sand, densely rooted throughout, root traces gelified, in part pyritized.

Schoe XXV/27 $(13 \mathrm{~cm})$ Dark silty clay, massive, light-colored silt layers widely dispersed, more concentrated at certain levels, upper $40 \mathrm{~cm}$ increasingly with bioturbation tubes filled with light-colored silt and fine sand, at top massive, \pm unbedded.

Schoe XXV/26 (32 cm) Dark clayey silt with some light-colored cross-bedded silt layers, similar to bed 24, but without bioturbation.

Schoe XXV/25 $(45 \mathrm{~cm})$ Dark silty clay with scattered silt laminae, massive, \pm unbedded, very rare lightcolored bioturbation tubes $(5 \mathrm{~mm})$.

Schoe XXV/24 (22 cm) Dark clayey silt bedded by thin light-colored silt layers, lower part unbedded with small pyrite nodules, basal contact sharp but disrupted by bioturbation.

Schoe XXV/23 (37 cm) Dark very silty clay, massive, rarely with light-colored silt layers, pyrite in upper part, bioturbation tubes $(5 \mathrm{~mm})$ terminating at top contact.

Schoe XXV/22 $(7 \mathrm{~cm})$ Grey silty clay with numerous silt laminae and lenses, sharp lower contact disrupted by bioturbation, small xylites, similar to bed Schoe XXV/6 below.

Schoe XXV/21 $(50 \mathrm{~cm})$ Dark clay finely bedded with light-colored silt layers and lenses and bioturbation tubes $(1 \mathrm{~mm})$, bioturbation tubes from top down $(5 \mathrm{~mm})$ filled with silt, equivalent to bed Schoe XXV/6 below.

Schoe XXV/20 (22 cm) Fine bedding of dark clayey and light-colored silt layers, no bioturbation, equivalent to bed Schoe XXV/6 below.

Schoe XXV/19 $(60 \mathrm{~cm})$ Light colored clayey silt with erosive base, darker and more clayey in densely bioturbated lower part $(29 \mathrm{~cm})$, pyrite nodules, upper part less bioturbated and with scattered xylites, equivalent to bed Schoe XXV/5 below.

Schoe XXV/18 (41 cm) Equivalent to bed Schoe XXV/7 below, \pm vertical to diagonal bioturbation tubes $(5 \mathrm{~mm})$ with light-colored silt filling, forams in upper part(?).

Schoe XXV/17 (19 cm) Equivalent to bed Schoe XXV/6, grey slightly clayey silt, flaser-bedded, scattered fine bioturbation tubes.

Schoe XXV/16 (150-160 cm) Equivalent to bed Schoe XXV/5 below, fining upward, mainly fine bioturbation tubes in lower $50 \mathrm{~cm}$, basal contact with erosional features.

Schoe XXV/15 $(50 \mathrm{~cm})$ Equivalent to bed Schoe XXV/8 below, but more sandy, upper $15 \mathrm{~cm}$ with dense bioturbation of randomly directed tubes $(2 \mathrm{~mm})$ filled with light-colored silt, sharp lower contact.

Schoe XXV/14 $(28 \mathrm{~cm})$ As bed Schoe XXV/7 below, more bioturbated at top, single xylite.

Schoe XXV/13 $(21 \mathrm{~cm})$ Equivalent to bed 6 below, alternation of dark clayey silt and light-colored silt laminae, in part fine cross-bedding (ripples), thin bioturbation tubes, sharp lower contact.

Schoe XXV/12 $(60 \mathrm{~cm})$ Beige brown flasered slightly clayey silt, in part densely bioturbated with fine tubes $(1 \mathrm{~mm})$, sharp lower contact.

Schoe XXV/11 $(23 \mathrm{~cm})$ Equivalent to bed Schoe XXV/8 below, mostly fine bedded with flat pebbles and layers or pockets with forams(?).

Schoe XXV/10 $(63 \mathrm{~cm})$ As bed Schoe XXV/7 
Schoe XXV/9 (51 cm) As bed Schoe XXV/5, fine bioturbation tubes randomly directed, single xylite at top, upward fine bedding.

Schoe XXV/8 $\quad(27 \mathrm{~cm})$ Dark brown homogeneous silty clay, unbedded, scattered pyritized bioturbation tubes, forams?, very sharp upper contact.

Schoe XXV/7 $\quad(67 \mathrm{~cm})$ Dark silty clay to clayey silt, compact, fine bedding throughout by fine light-colored silt lamina, no bioturbation.

Schoe XXV/6 $(10 \mathrm{~cm})$ Transitional, fine bedding of dark clayey $(5 \mathrm{~mm})$ and light-colored silty layers $(2-3 \mathrm{~mm})$, no bioturbation.

Schoe XXV/5 $(22 \mathrm{~cm})$ Light-colored clayey silt with sharp slightly erosive lower contact, irregular flaser-to lenticular bedding, clay content increasing upward, xylite at base, no bioturbation.

Schoe XXV/4 $\quad(22 \mathrm{~cm})$ Dark silty clay, massive, but internally bedded by light-colored silt layers with abundant mica, top $4 \mathrm{~cm}$ with fine bioturbation, lower contact disturbed (see below).

Schoe XXV/3 $\quad(33 \mathrm{~cm})$ Light-colored medium to coarse sand with some Ophiomorpha tubes and fragments of xylite, desiccation structures disrupting upper contact.

Schoe XXV/2 $\quad(11 \mathrm{~cm})$ Light-colored fine to medium sand with somewhat indurated dark flasers and a $2 \mathrm{~cm}$ thick dark layer (secondary coloration?), no bedding recognizable.

Schoe VI/24 (46 cm) Dark, more or less clayey silt with layers of dark sand including partially pyritized charcoal fragments; individual layers with foraminifera?, plant remains present and partially pyritized, common slickensides.

\section{Base of Interbed 3}

\section{Top of Seam 2}

Schoe XXV/1 (Open end) Dark xylitic lignite, medium brown when fresh, abundant gelified tissue, bioturbation tubes $(5 \mathrm{~mm})$ from top down to $5 \mathrm{~cm}$ filled with brown to light-colored sand.

Schoe VI/22 (18 cm) Medium brown TML, charcoal lenses at base, light colored xylites increasingly common toward top, projecting into overlying sediments at top.

Schoe $\mathrm{VI} / 21 \quad(14 \mathrm{~cm})$ As bed 19, but more massive, less finely dispersed charcoal, less rooting, fewer silt pockets, no fern axes.

Schoe VI/20 (8 cm) As bed 19, but not bedded, no fern axes.

Schoe VI/19 $(15 \mathrm{~cm})$ Medium brown TML, intensely rooted with redbrown root traces, distinctly bedded, small charcoal fragments on bedding plains, light colored tissue common, scattered pockets of silt and pyrite, some xylites, possibly fern axes.

Schoe $\mathrm{VI} / 18 \quad(33 \mathrm{~cm})$ Medium light colored to brown TML with numerous tissue remains: light colored tissue and charcoal, scattered charcoal lenses in lower and upper part, missing in middle; in upper part strikingly light colored xylites.

Schoe VI/17 (18 cm) Dark to medium brown ML with individual layers of tissues, fine rooting, at base 1 to $2 \mathrm{~cm}$ thick layer finely bedded by charcoal particles (reworked from bed 16).

Schoe VI/16 $\quad(9 \mathrm{~cm})$ Somewhat degraded medium brown TL with numerous charcoal fragments and particles and small plant remains, bed bounded at base and top by 1 to $2 \mathrm{~cm}$ thick xylites charred on lower side; laterally changing thickness.

Schoe VI/15 $\quad(167 \mathrm{~cm})$ Medium brown TML with some gelified tissues and xylite fragments, charcoal also concentrated in lenses, numerous light brown tree stumps not horizontally aligned, large xylites, irregular bedding, but no banding as in lower part of the seam. Resin particles present.

Schoe $\mathrm{VI} / 14$ $(1-2 \mathrm{~cm})$ Friable charcoal layer.

Schoe $\mathrm{VI} / 13 \quad(16 \mathrm{~cm})$ As bed 12, but somewhat darker, root traces more frequent and mostly gelified.

Schoe $\mathrm{VI} / 12 \quad(7 \mathrm{~cm})$ Light colored $\mathrm{ML}$ with light colored tissues, scattered xylites and common root traces, fine bedding indicated, rare charcoal.

Schoe VI/11 $(29 \mathrm{~cm})$ Medium light colored TML with light colored tissues as in bed 9, no notable rooting, common charcoal layers.

Schoe $\mathrm{VI} / 10 \quad(11 \mathrm{~cm})$ Light colored $\mathrm{ML}$ with more or less gelified root traces, scattered charcoal and gelified tissues, $2 \mathrm{~cm}$ thick charcoal layer on top. 
Schoe VI/9 (33 cm) Medium light colored TML with numerous light colored tissue, partly in lenses, partly randomly distributed and finely fractured; fine dark root traces diagonally and horizontally to bedding, upward increasing in number, no gelified root branches, no resin, scattered charcoal lenses.

Schoe VI/8 (26 cm) Dark TML, well bedded, with gelified and charred tissue on bedding planes, charcoal layers mainly in upper part.

Schoe $\mathrm{VI} / 7 \quad(38-42 \mathrm{~cm})$ Light colored $\mathrm{ML}$ with numerous light colored tissue remains and in part large resin grains concentrated in layers; dark layer with partially charred xylites in middle, thick gelified root traces in upper part.

Schoe VI/6 $(6 \mathrm{~cm})$ Light colored $\mathrm{ML}$ with gelified tissues and resin particles, strikingly light colored in weathered section, laterally with horizontally embedded xylites.

Schoe VI/5 (22 cm) Dark TML with numerous xylites and light colored tissues, reddish in fresh cut, internal fine bedding, blocky fracture, resin particles and gelified root cross sections.

Schoe $\mathrm{VI} / 4 \quad(19 \mathrm{~cm})$ Medium light ML with gelified and light colored tissue remains, several robust gelified root traces, resin particles in upper part.

Schoe VI/3 (18 cm) Dark TML with numerous gelified tissues and partly not gelified xylites, somewhat clayey?

Base of Seam2

Top of Interbed 2

Schoe $\mathrm{VI} / 2 \quad(2 \mathrm{~cm})$ Transition to Seam 2; dark silty clay with numerous gelified root traces and plant remains, slickensides, scattered xylites, small resinous plant remains common (conifer twigs?).

Schoe $\mathrm{VI} / 1 \quad$ (Open end) As bed Schoe V/34.

Schoe $\mathrm{V} / 34 \quad(15 \mathrm{~cm})$ Dark greyish brown silty clay, permeated by broad coaly root traces increasing upward in number; no bedding, frequent slickensides, pyrite in small concretions; scattered plant remains and detritus.

Schoe V/33 $\quad(6.5 \mathrm{~cm})$ Dark brown clayey silt to silty clay, with scattered silt layers, plant detritus, coaly pebbles, coaly root traces; in upper part also layers with fine bedding, common resin particles.

Schoe V/32 (12 cm) Dark silty clay, homogeneous, with rare silt laminae, scattered small coaly lenses and fine vertical coaly root traces.

Schoe V/31 $(10 \mathrm{~cm})$ Dark clayey silt with laminae of light colored silt and fine sand, pyrite?, foraminifera?

Schoe V/30 (11 cm) Dark silty clay with laminae and lenses of light colored fine sand, low angle crossbedding, vertical bioturbation tubes, in part pyritized.

Schoe V/29 $(6 \mathrm{~cm})$ Light colored to white fine sand to medium? Sand, locally cross-bedded.

Schoe V/28 (1 cm) Dark grey (black when fresh) silty clay with silt laminae, irregular contact with underlying and overlying beds.

Schoe V/27 (36 cm) Light colored fine sand with clayey layers, wavy-flasered bedding marked by dark clay laminae, clay fraction very dark to black (carbonaceous?), thin vertical bioturbation tubes, rare cup-shaped depressions.

Schoe V/26 $(33 \mathrm{~cm})$ Light colored fine sand, distinct cross-bedding marked by clayey layers and laminae, cup-shaped bioturbation imprints (?) common and scattered bioturbation tubes ( $\varnothing 1$ to $2 \mathrm{~cm}$ ).

Schoe V/25 (33 cm) Light colored to white fine sand, slightly coarsening upward, two layers near base and middle with flaser- and cross-bedding indicated by clay drapes and laminae. Sand with horizontal and fine vertical bioturbation tubes, rather frequent in upper part, in lower part cup-shaped depressions up to $2 \mathrm{~cm}$ in diameter (bioturbation?).

Schoe V /24 $(9 \mathrm{~cm})$ Dark greyish brown silty clay with laminae of silt and fine sand in lower part, in upper part more massive, no bioturbation; irregular base.

Schoe V/23 (33 cm) As bed Schoe V/21. 4-5cm thick dark clay layer in middle, proportion of fine sand increasing upward.

Schoe V/22 $\quad(29 \mathrm{~cm})$ As bed Schoe V/20. 
Schoe V/21 $(33 \mathrm{~cm})$ Light colored fine sand in irregular lenses and layers partly with distinct crossbedding, some clay layers and scattered fine bioturbation.

Schoe V/20 (44 cm) Dark silty clay with numerous lenses and laminae of fine sand partly with crossbedding, fine bioturbation.

Schoe V/19 $(40 \mathrm{~cm})$ Fivefold alternation of dark silty clay and laminae of light colored fine sand, in part with cross-bedding, layers of fine sand regularly cross-bedded; lower half mixture of sand and clay layers, charcoal and plant detritus in upper sand layer.

Schoe V/18 $\quad(37 \mathrm{~cm})$ Laminae and lenses of light colored fine sand with distinct cross-bedding, channels with clay laminae and layers, bioturbation in clayey layers.

Schoe V/17 $(32 \mathrm{~cm})$ Dark silty clay with laminae and lenses of fine sand, more common upward, there in part with bimodal cross-bedding.

Schoe V/16 (15 cm) As bed Schoe V/14; not as hard, slightly more clayey, somewhat bedded by laminae of silt and fine sand, locally fine bedding; foraminifera present.

Schoe V/15 $(12 \mathrm{~cm})$ As bed Schoe V/13; laminae of silt and fine sand more frequent.

Schoe V/14 $(7.5 \mathrm{~cm})$ Dark grey clayey silt, no recognizable bedding, homogeneous, fracturing irregularly, hard; scattered fine bioturbation tubes, irregular boundary at top.

Schoe V/13 $(28 \mathrm{~cm})$ Dark brown clayey silt with light colored laminae and lenses of silt and fine sand, in layers finely bedded with cross-bedding, thin bioturbation tubes.

Schoe V/12 (115 cm) Dark grey highly clayey silt, massive, with scattered silt laminae at some levels, completely homogeneous, concoidal fracture.

Schoe V/11 (9 cm) Dark grey highly silty clay, homogeneous in appearance, but with few distinct light colored silt laminae, fine bioturbation tubes recognizable in silt laminae.

Schoe V/10 $(22 \mathrm{~cm})$ Dark grey clayey silt with very fine laminae of light colored fine sand and silt, thin bioturbation tubes, distinct light/dark lamination.

Schoe V/9 $\quad(10 \mathrm{~cm})$ Dark silty clay, totally homogeneous, unstructured.

Schoe V/8 $\quad(15 \mathrm{~cm})$ Greyish brown silty clay with thick lenses and flasers of light colored silt and fine sand, frequently fine sand in bioturbation tubes.

Schoe V/7 (28 cm) Brownish grey, highly silty clay with layers and lenses of light colored fine sand, internal fine bedding, pyrite concretions common.

Schoe V/6 $\quad(12 \mathrm{~cm})$ Medium to light grey, clayey silt with light colored flasers and lenses of fine sand and silt, some layers with charcoal.

Schoe V/5 (12 cm) Dark greyish brown clayey silt, homogeneous in appearance, but internally finely laminated, lenticular pyrite concentrations, charcoal fragments, scattered sand flasers, light colored $0.5 \mathrm{~cm}$ thick sandy layer at base.

Schoe V/4 $\quad(16 \mathrm{~cm})$ Medium grey silty clay, finely laminated, ostracod steinkerns on bedding planes, scattered charcoal fragments, $1 \mathrm{~cm}$ in size.

Schoe V/3 $\quad(9.5 \mathrm{~cm})$ Medium grey silty clay with light yellowish laminae and flasers of silt to fine sand, locally bioturbation, scattered charcoal and fine root traces.

\section{Base of Interbed 2}

Top of Seam 1

Schoe IX/58 (22 cm) Dark greyish brown TL to TML, well bedded, bedding planes covered with charcoal fragments, gelified tissues and clay drapes, bioturbation tubes and voids filled with kaolinite(?) increasingly common upward, pyrite clusters in upper part.

Schoe IX/57 (18 cm) Dark brown TML to ML (in middle), internal fine bedding, charcoal concentrated on bedding planes, red root traces scattered, but common in middle; striate pyritized tubes in upper part.

Schoe IX/56 (24 cm) Brown TML with light colored tissue concentrated in layers together with small gelified tissue fragments, dispersed charcoal, scattered resin and gelified tissue, few red root traces. 
Schoe IX/55 (19 cm) Reddish brown TML with red root traces, charcoal on bedding planes; light colored tissue in upper part, at top distinct layer of charcoal, laterally replaced by xylite.

Schoe IX/54 (22 cm) Reddish brown TML, reddish in fresh cut, few reddish root traces, some charcoal layers and lenses, numerous gelified tissue, scattered small pyrite clusters.

Schoe IX/53 (52 cm) Medium brown TML to TL, reddish mottled, with numerous charcoal fragments dispersed and in layers; reddish root traces throughout, some small pyrite concretions, tissue remains partly gelified or pyritized; xylites concentrated near top, increasingly gelified and in part charred.

Schoe IX/52 (54 cm) Medium brown tissue bearing ML, reddish in fresh cut, with fine gelified tissue fragments and isolated xylites, succession of charcoal layers and lenses, light colored tissue present, no pyrite; distinct internal bedding.

Schoe IX/51 (22 cm) Dark mixed tissue/matrix lignite lithotype (TML) with numerous fine gelified tissue fragments, isolated xylites and few small pyrite concretions ( $\varnothing 1-2 \mathrm{~mm})$, partly within xylites, some resin and charcoal fragments, charcoal in part associated with xylites, distinct charcoal layer (about $1 \mathrm{~cm}$ ) at top.

Schoe IX/50 $\quad(20 \mathrm{~cm})$ Medium light colored reddish ML with some light colored tissue, xylites and resin occurring regularly, reddish root traces in upper part; top boundary transitional.

Schoe IX/49 (19 cm) Dark ML, reddish in fresh cut, including layers with small tissue fragments and some xylites, small pyrite concretions common, also occurring within partially charred xylites; scattered charcoal at top.

Schoe IX/48 $(19 \mathrm{~cm})$ Dark brown matrix dominated lignite lithotype $(\mathrm{ML})$ with some gelified and light colored tissues; xylites common, distinct charcoal layer at top.

\section{Base of Seam1}

\section{Top of Interbed 1}

Schoe IX/47 (20 cm) Medium to dark greyish brown clay with sand lenses, numerous root branches (tree stumps?), frequent slickensides.

Schoe IX/46 (18 cm) Dark brown silty clay with intermittent laminae, lenses and layers of silt to fine sand, no bedding, some flat lying root branches.

Schoe IX/45 (42 cm) Dark silty clay with dispersed sand, layers and lenses of light-colored medium sand up to $1 \mathrm{~cm}$ thick at base and top, near base distinctly bioturbated, in upper part lenticular and flaser-bedding, decreasing bioturbation, scattered rooting and sand-filled bioturbation tubes.

Schoe IX/44 (32 cm) Very dark silty clay with numerous small pyrite aggregates, forams(?), silt laminae and flasers in middle of bed, upward some sand-filled bioturbation tubes, one vertical gel-filled tube $1 \mathrm{~cm}$ wide.

Schoe IX/43 $\quad(3 \mathrm{~cm})$ Light-colored silt laminated by dark clay laminae.

Schoe IX/42 $(28 \mathrm{~cm})$ Very dark silty clay with numerous small pyrite aggregates, forams(?), scattered vertical sand-filled tubes and pyrite concretions, silt laminae in upper part.

Schoe IX/41 (23 cm) Medium gray silty clay, bedded by some silt laminae and bioturbation parallel to bedding.

Schoe IX/40 (94 cm) Beige brown clayey silt, in part fine bedding by thin silt layers, flasers and laminae, dense bioturbation parallel to bedding, in part vertical tubes crossing silt layers.

Schoe IX/39 (38 cm) Beige brown clayey silt, no bedding due to intensive bioturbation.

Schoe IX/38 $\quad(22 \mathrm{~cm})$ Beige brown clayey silt at base grading into silty clay upward with silt laminae and flasers and dense bioturbation parallel to bedding.

Schoe IX/37 (22 cm) Dark slightly silty clay, unbedded, densely bioturbated by thin randomly oriented pyritized tubes.

Schoe IX/36 $(32 \mathrm{~cm})$ Medium brown clayey silt to light-colored silt at top, bedded, but intensely bioturbated parallel to bedding, vertical in part pyritized tubes in upper $8 \mathrm{~cm}$.

Schoe IX/35 $(22 \mathrm{~cm})$ Dark slightly silty clay, fine bedded by silt lamina, fine pyritized bioturbation tubes, pyrite concretions common. 
$(11 \mathrm{~cm})$ Medium gray clayey silt, bedded by silt laminae, intensely bioturbated parallel to bedding, partly with fine pyritized tubes.

Schoe IX/33 $\quad(26 \mathrm{~cm})$ Dark slightly silty clay, massive with few silt laminae.

Schoe IX/32 (12 cm) Slightly clayey silt to pure silt, intensely bioturbated parallel to bedding, distinctly lighter than bed Schoe IX/31.

Schoe IX/31 (50 cm) Medium gray brownish silty clay to clayey silt with dense horizontal bioturbation, nearly no bedding.

Schoe IX/30 $\quad(11 \mathrm{~cm})$ Light-colored, slightly clayey silt, densely bioturbated, $2 \mathrm{~cm}$ light beige pure silt at top.

Schoe IX/29 $(28 \mathrm{~cm})$ Dark gray silty clay with few light-colored silt laminae, very fine bedding at some levels, no pyrite, bioturbation entering from top.

Schoe IX/28 $(38 \mathrm{~cm})$ Brown gray to greenish gray clayey silt, somewhat lighter than bed Schoe IX/27 densely bioturbated by \pm horizontal tubes filled with light-colored silt, bioturbation particularly dense at base, scattered coaly particles.

Schoe IX/27 (44 cm) Medium gray slightly greenish clayey silt, completely bioturbated by horizontal tubes with color as background sediment, finely dispersed pyrite.

Schoe IX/26 (34 cm) Dark brown silty clay, densely bioturbated by \pm horizontal tubes filled with lightcolored silt especially in lowermost $3-5 \mathrm{~cm}$, pyrite concentration at base.

Schoe IX/25 (25 cm) Irregular alternation of light gray clayey silt and light-colored silt/fine sand, silt increasing upward, thin vertical sand-filled bioturbation tubes and horizontal bioturbation, no bedding.

Schoe IX/24 $(6 \mathrm{~cm})$ Brown silty clay, densely bioturbated by horizontal tubes, some vertical sand-filled tubes, small pyrite concretions, no bedding.

Schoe IX/23 $(75 \mathrm{~cm})$ Light beige alternation of clayey silt and somewhat lighter colored silt with fine sand, mica content increasing with fine sand, some pyrite concretions.

Schoe IX/22 (68 cm) Light gray slightly clayey silt, proportion of silt and mica increasing upward, small pyrite nodules in layers of lower part.

Schoe IX/21 $(11 \mathrm{~cm})$ Light gray silt with fine sand, homogeneous, no bedding.

Schoe IX/20 (19 cm) Light beige silty clay to clayey silt with mica in upper part, clay fraction increasing upward.

Schoe IX/19 $(70 \mathrm{~cm})$ Light gray silt to clayey silt with some fine sand, bedding locally indicated, no bioturbation, no rooting, but slide structures throughout.

Schoe IX/18 $(74 \mathrm{~cm})$ Fivefold alternation of light-colored fine sand and slightly darker silt with fine sand, some bioturbation, cross-bedding indicated in sand layers, no rooting.

Schoe IX/17 (44 cm) Light gray silt to fine sand, some layers of slightly darker silt with bioturbation transitional to sandy layers.

Schoe IX/16 $(52 \mathrm{~cm}) \pm$ distinct alternation of light gray silt and light-colored fine sand, partly obscured by bioturbation, coaly root branches in upper part.

Schoe IX/15 $(48 \mathrm{~cm})$ Light gray silt with fine sand, locally horizontal bioturbation obscuring primary bedding(?), no rooting, scattered pyrite concretions at top.

Schoe IX/14 $(60 \mathrm{~cm})$ Light gray silt with fine sand and mica, light medium sand in irregular layers and lenses, fine carbonaceous roots present and decreasing towards the top, single organic-rich layers; single carbonaceous hollow axes.

Schoe IX/13 $(15 \mathrm{~cm})$ Almost white medium sand with occasional, slightly siltier parts, rooted throughout, with fine carbonaceous remains of axes $\varnothing 1 \mathrm{~cm}$ (?branches).

Schoe IX/12 $(40 \mathrm{~cm})$ Light gray clayey silt to fine sand, some organic layers in the lower part; densely interspersed with fine roots, irregularly wavy stratification.

Schoe IX/11 (30 cm) Fine to medium sand, light gray to white, with a few flasers of clayey silt; densely interspersed with fine carbonaceous roots, regularly interspersed with thick carbonaceous and in parts hollow axes (?roots). 

intercalations of light gray clayey silt, fine rooting, bioturbation in silt layers increasing upward.

Schoe IX/9 $(8 \mathrm{~cm})$ Light gray clayey silt with occasionally organic layers, concentrated at the top, fine vertical bioturbation tubes, but less than in layer Schoe IX/8.

Schoe IX/8 $\quad(30 \mathrm{~cm})$ As bed Schoe IX/6, but more bioturbated, pronounced layer of medium sand at the top.

Schoe IX/7 (11 cm) Double bed of light gray clayey silt, separated by $2 \mathrm{~cm}$ fine to medium sand, \pm vertical thin sand-filled tubes; isolated charcoal remains.

Schoe IX/6 $\quad(84 \mathrm{~cm})$ Alternation of organic layers, silty clay/clayey silt, beige to light gray fine to medium sand, overall wavy and flaser bedding, $10 \mathrm{~cm}$ below top medium sand layer with clayey and organic flasers, no bioturbation at the base, at approx. $30 \mathrm{~cm}$ increasing individual \pm vertical tubes filled with sand $(\varnothing$ up to $0.5 \mathrm{~cm}$ ), no cross-bedding.

Schoe IX/5 (29 cm) Alternation of brown clayey silt, light gray layers of fine sand and thin organic layers in part cutting into underlying bed.

Schoe IX/4 $\quad(10 \mathrm{~cm})$ Reddish brown clayey fine sand with much mica and carbonaceous layers.

Schoe IX/3 $\quad(31 \mathrm{~cm})$ Alternation of light brown clayey silt and light-colored layers of silt/fine sand, commonly in lenses and flasers, xylite with much pyrite $17 \mathrm{~cm}$ above base.

Schoe IX/2 (5-6 cm) Light gray clayey silt well-bedded by darker clayey flasers and layers.

Schoe XLIX $29 \quad(>50 \mathrm{~cm})$ Massive grey silty clay with small pyrite lenses.

Base of Interbed 1

Top of Main Seam

Schoe XLIX/28 $(2-3 \mathrm{~cm})$ Dark grey carbonaceous clay with some charcoal and xylites, sharp lop boundary.

Schoe IX/1 (30 cm) Dark brown bedded mixed matrix/tissue lignite lithotype with light-colored tissue, charcoal and pyrite, scattered sand veins.

Schoe XLIX/27 (52 cm) Carbonaceous clay lo clayey lignite, greenish in lower part, transitional lo dark-brown above, numerous colored tissue in upper part, scattered charcoal, gelification in lenses, resin dispersed, reddish root traces.

Schoe XLIX/26 $(20 \mathrm{~cm})$ Light brown to greenish brown clayey matrix lithotype with partially gelified xylites, intensely penetrated by brown streaks (roots), scattered resin, light colored tissue and charcoal.

Schoe XLIX/25 (18 cm) Dark to medium grey carbonaceous clay to pure clay, completely penetrated by slickensides, numerous in part thick xylites, light colored tissue in layers, scattered charcoal, reddish root traces.

Schoe XLIX/24 $(10 \mathrm{~cm})$ Light brown to pale matrix lithotype, intensely penetrated by medium brown streaks (roots), roots partially gelified, isolated xylite and partially pyritized charcoal slickensides rare.

Schoe XLIX/23 $(15 \mathrm{~cm})$ Dark clayey lignite to carbonaceous clay with xylites, charcoal inlayers penetrated by reddish root traces, scattered resin in layers numerous slickenside, bedding indicated.

Schoe XLIX/22 $(0-3 \mathrm{~cm})$ Very light-colored clay layer.

Schoe XLIX/21 (120 cm) Medium to light brown mixed tissue/matrix lithotype, numerous xylite, intense rooting with reddish root traces, dark layer $(5-10 \mathrm{~cm}$ ] with abundant charcoal in middle charcoal otherwise dispersed, resin scattered and in lenses, light colored tissue near top.

Schoe XLIX/20 (17 cm) Dark brown lo dark olive grey clayey lignite with partially charcoalified xylites, dispersed charcoal, minute resin grains, intense rooting with red sides common.

Schoe XLIX/19 (39 cm) Greenish light brown matrix lithotype, numerous thick xylites mainly in upper part, light colored tissue commonly xylite bound, scattered resin and charcoal.

Schoe XLIX/18 $(8 \mathrm{~cm})$ Heterogeneous layer, friable with clay laminae, much pyritized charcoal, xylites common. 
Schoe XLIX/17 $(26 \mathrm{~cm})$ Medium to light brown matrix lithotype with partially gelified xylites, numerous resin particles, densely rooted some light-colored tissue, rare charcoal.

Schoe XLIX/16 (41 cm) Dark carbonaceous clay with some thick xylites, intensely penetrated by slickensides, scattered resin.

Schoe XLIX/15 (13-16 cm) Light brown to pale (weathered) slightly clayey matrix lithotype, numerous small resin particles, scattered xylites and slickensides, no charcoal.

Schoe XLIX/14 (10-15 cm) Dark clayey lignite to carbonaceous clay with some tissue, reddish brown mottled numerous slickensides, scattered charcoal and xylites, rooted.

Schoe XLIX/13 $(27 \mathrm{~cm})$ Light brown mixed tissue/matrix lithotype, frequent xylites mainly at top, top heavily pyritized, resin common partly within tissue, scattered charcoal.

Schoe XLIX/12 (18 cm) Dark clayey lignite with numerous slickensides, scattered xylites, rare resin, less densely rooted.

Schoe XLIX/11 (23 cm) Light brown tissue lithotype, numerous xylites, intense fine rooting, scattered resin and charcoal, resin-rich xylite at top.

Schoe XLIX/10 (12 cm) Dark clayey lignite to carbonaceous clay with xylite parallel to bedding, some resin, light colored tissue and charcoal, slickensides common, internal fine bedding, no rooting.

Schoe XLIX/9 (24 cm) Pale brown matrix lithotype with some tissue, xylites, and light-colored tissue, numerous black root traces, some slickensides, no charcoal.

Schoe XLIX/8 (22 cm) Dark clayey lignite to carbonaceous clay, intensely penetrated by slickensides, scattered xylites and charcoal.

Schoe XLIX/7 $\quad(20-22 \mathrm{~cm})$ Medium brown matrix lithotype with some tissue, bedded at $1-2 \mathrm{~cm}$ scale with clay laminae, charcoal and xylites parallel to bedding, no rooting.

Schoe XLIX/6 $(65 \mathrm{~cm})$ Greenish grey slightly clayey lignite rich in tissue, intensely penetrated by fine roots, in part distinct charcoal lenses, scattered xylites and light-colored tissue.

Schoe XLIX/5 (1-4 cm) Pale greyish brown clay layer with light colored clay laminae, fine tissue detritus, scattered charcoal and xylite, slickensides.

Schoe XLIX/4 (115 cm) As bed Schoe XLIX/3 but with much more charcoal lenses, some light-colored tissue and resin, charcoal in part pyritized, lowermost part greenish grey.

Schoe XLIX/3 $\quad(110 \mathrm{~cm})$ Dark brown highly xylitic lignite, xylites dominating over matrix, reddish in fresh cut, abundant charcoal partly in massive lenses, scattered light colored tissue, fine rooting, samples taken from matrix.

Schoe XLIX/2 $(8 \mathrm{~cm})$ Greenish grey clayey lignite with some xylites and charcoal, light-colored tissue rare, numerous light grey clay lamina transitional light-colored clay layer, fine rooting.

Schoe XLIX/1 (145 cm) Xylitic lignite, xylites reddish in fresh cut, embedded in greenish brown somewhat clayey matrix, numerous tissue and charcoal particles, some resin particles, light-colored tissue rare, fine reddish brown root traces. 
Fig. S1 Lithological logs of the seven sections from the Schöningen Formation. Grain size distribution is based on filed observations. Numbers indicate described horizons (see above). The different colors are reflecting the sediment/lignite colors.

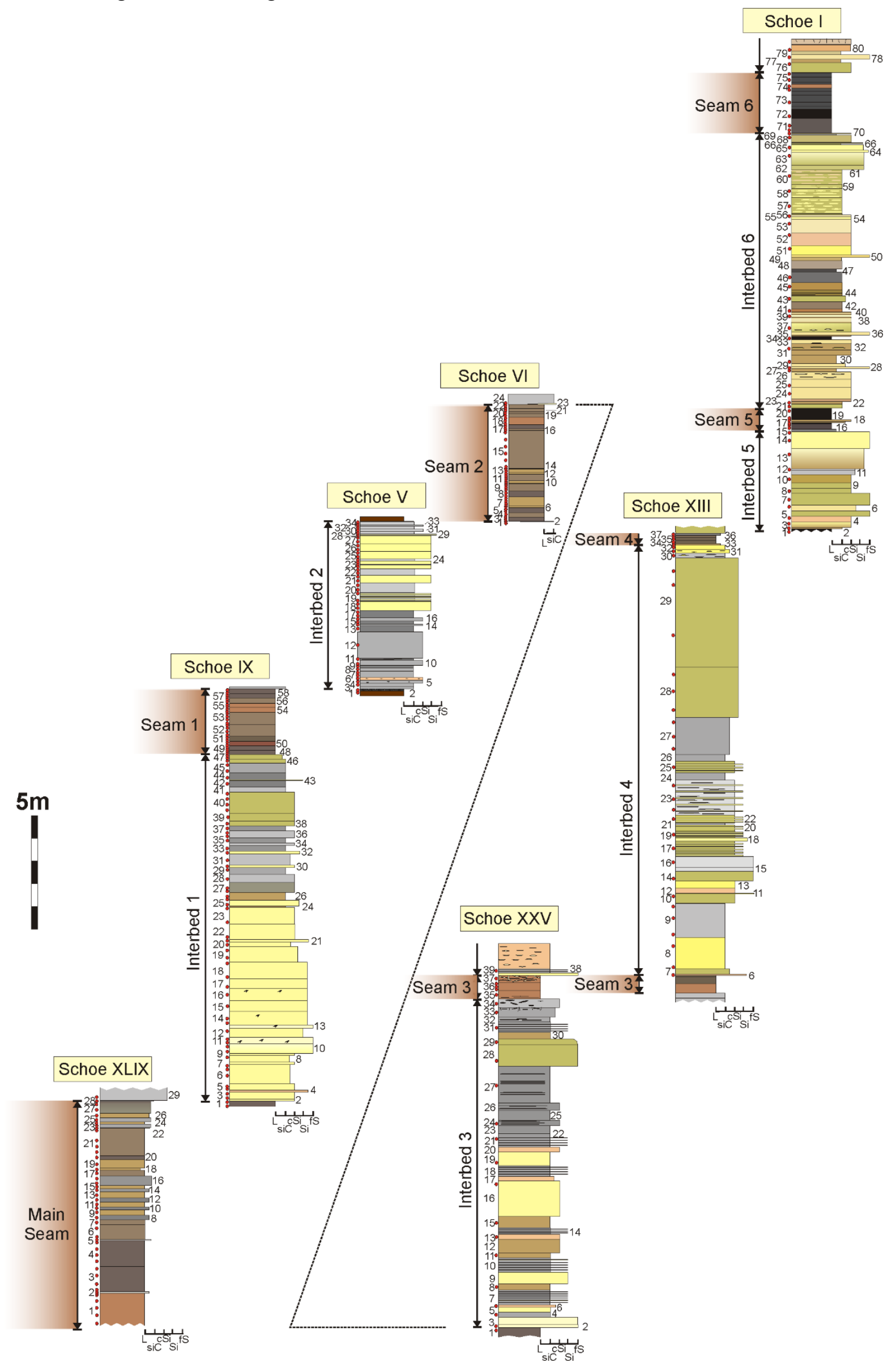




\section{S2 Panels}

Fig. S2: Apectodinium species (SEM pictures) from interbeds of the lower part of the Schöningen Formation. The scale bars represent $10 \mu \mathrm{m}$. (A) Apectodinium homomorphum (Interbed 2); (B) Apectodinium homomorphum (Interbed 2); (C) Apectodinium longispinosum (Interbed 2); (D) Apectodinium parvum (Interbed 2); (E) Apectodinium quinquelatum (Interbed 1)
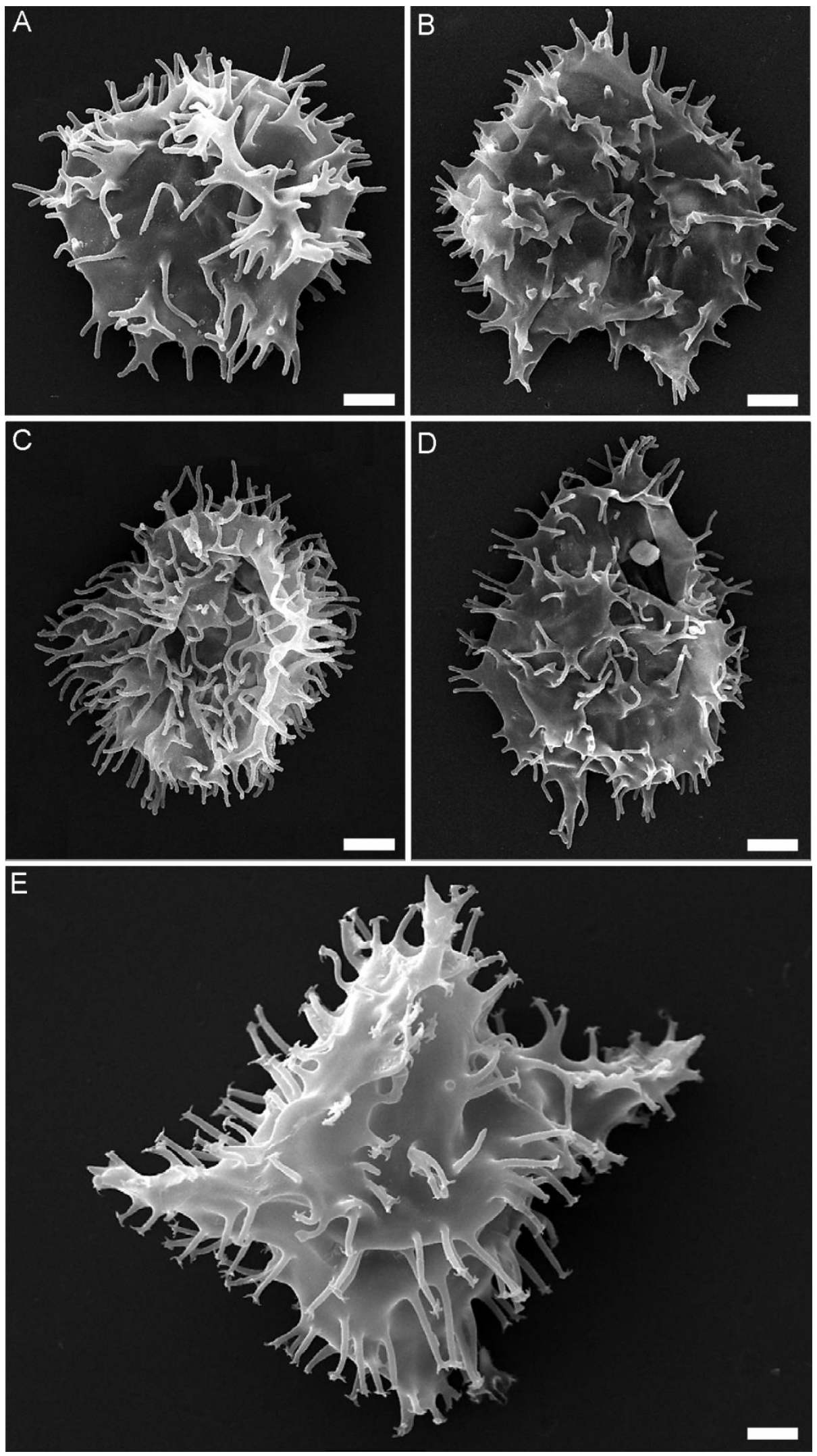
Fig. S3: Selected dinoflagellate cysts (SEM pictures) from Interbed 2 of the Schöningen Formation. The scale bars represent $10 \mu \mathrm{m}$. (A), (C) Cleistosphaeridium placacanthum/ancyreum complex: (A) Cleistosphaeridium ancyreum, (C) Cleistosphaeridium sp.; (B) Cordosphaeridium gracile; (D) Spiniferites ramosus; (E) Cribroperidinium tenuitabulatum; (F) Cordosphaeridium fibrospinosum
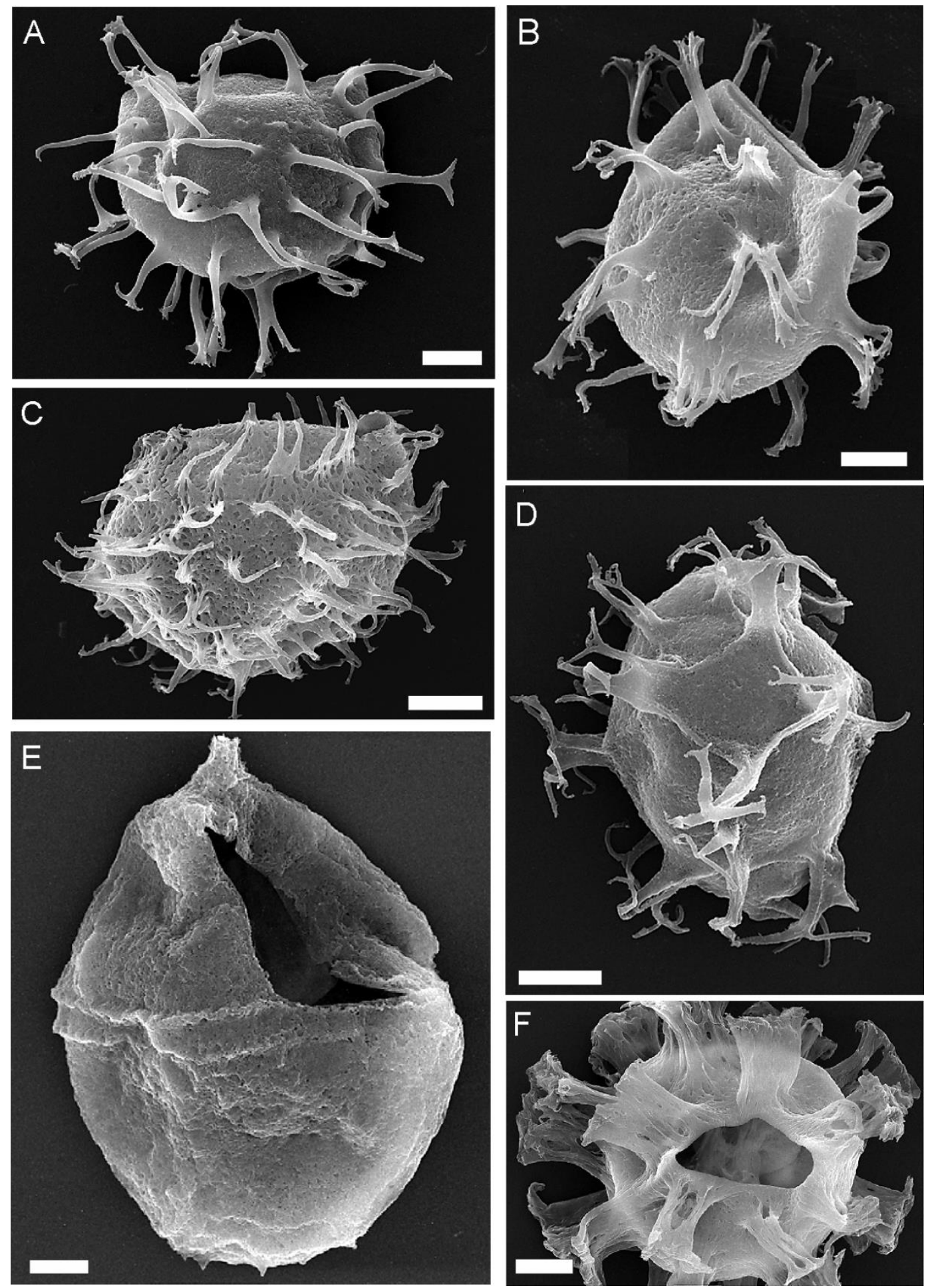
Fig. S4: Selected dinoflagellate cysts (LM pictures) from Interbed 3 of the Schöningen Formation. The scale bars represent $20 \mu \mathrm{m}$. (A) Cordosphaeridium fibrospinosum; (B) Cleistosphaeridium placacanthum/ancyreum complex; (C) Homotryblium tenuispinosum; (D) Glaphyrocysta ordinata; (E) Hystrichokolpoma rigaudae; (F) Hystrichokolpoma cinctum; (G) Thalassiphora pelagica; (H) Achomosphaera crassipellis;

(I) cf.

Phthanoperidinium
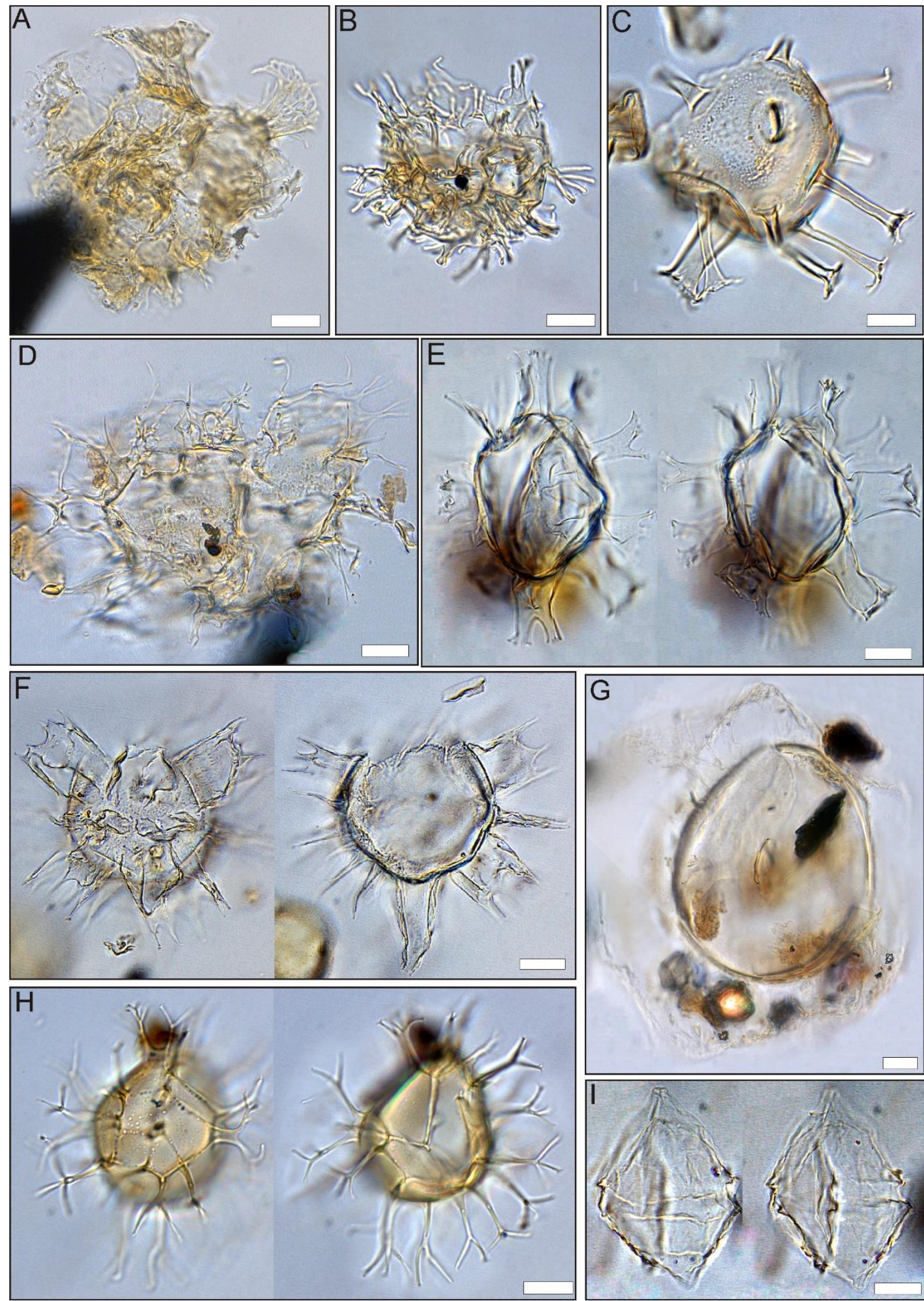


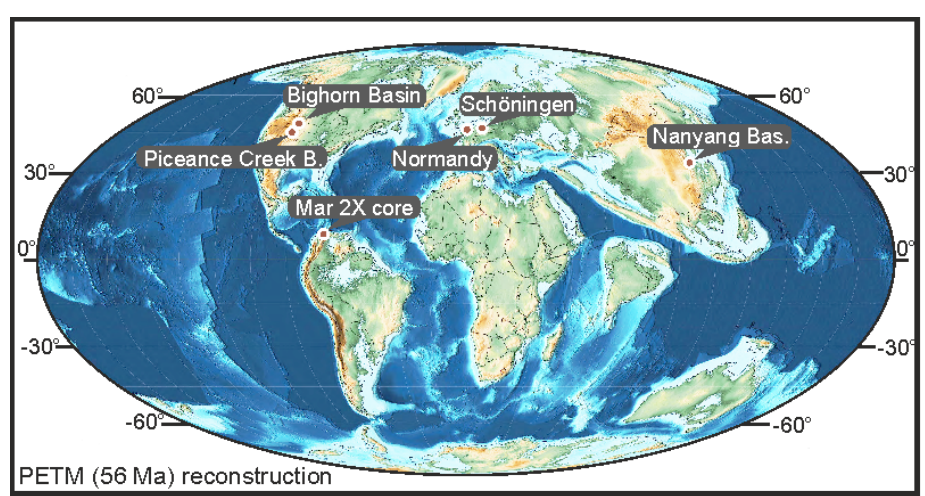

Fig. $\mathbf{S 5}$ (extension of Fig. 6 in the main text) Comparison of $\delta^{13} \mathrm{C}$ data for the Paleocene-Eocene Thermal Maximum (PETM) in continental/marginal marine records indicating that non-marine records commonly show a rebound to higher ${ }^{13} \mathrm{C}$ values during the CIE body (black arrows). Data for continental and marginal marine records: Polecat Bench, Bighorn Basin, USA (Baczynski et al., 2013); North Butte, Bighorn Basin, USA (Bataille et al., 2013); Wasatch Formation, Piceance Creek Basin, Colorado, USA (Foreman et al., 2012), the black line corresponds to a 5-point running mean of bulk data; Mar $2 X$ core, Venezulea (Jaramillo et al., 2010), the black line corresponds to a 5-point running mean of bulk data; Vasterival, France (Storme et al., 2012), Beigou section, Nanyang Basin, central China (Chen et al., 2014). Locations of the study sites are presented on a continental reconstruction for the PETM (PALEOMAP project, Map 14; Scotese, 2014) Abbreviations for stable carbon isotope data: $\delta^{13} \mathrm{C}_{\mathrm{DOM}}$ - measurements of dispersed organic matter, $\delta^{13} \mathrm{Corg}$ - measurements of organic matter; $\delta^{13} \mathrm{C}_{\mathrm{DOC}}$ - measurements of dispersed organic carbon; $\delta^{13} \mathrm{C}_{\text {TOC }}$ - measurements of bulk organic matter; $\delta^{13} C_{B C}$ - measurements of black carbon.
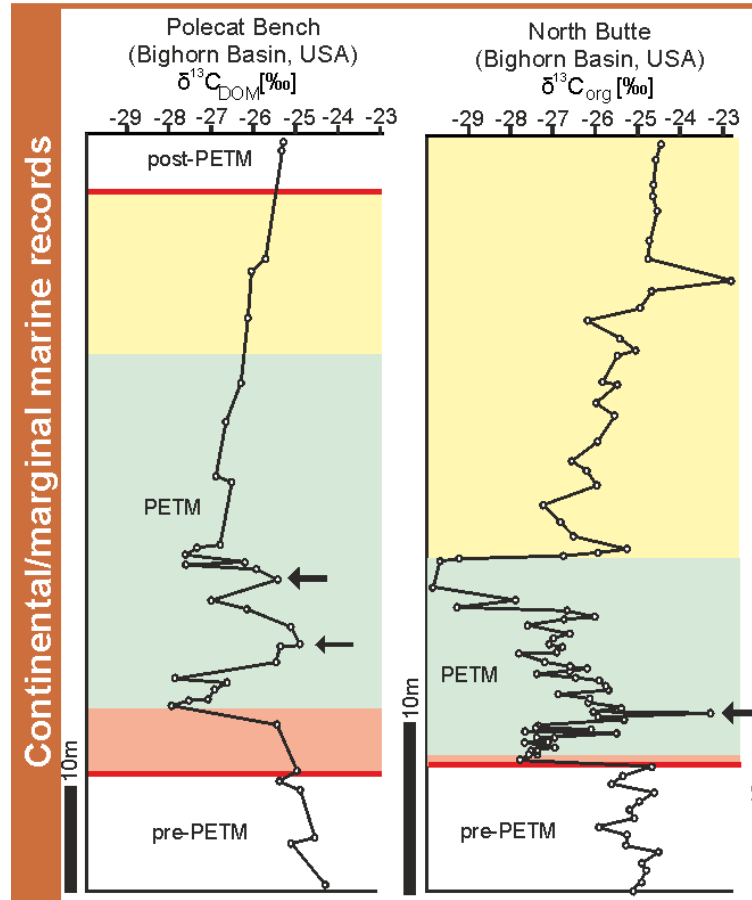

Wasatch Form.,Piceance Creek B.
(Colorado, USA) (Colorado, USA)

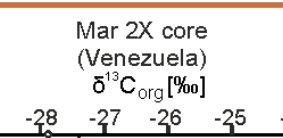

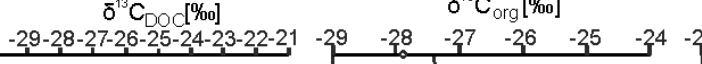
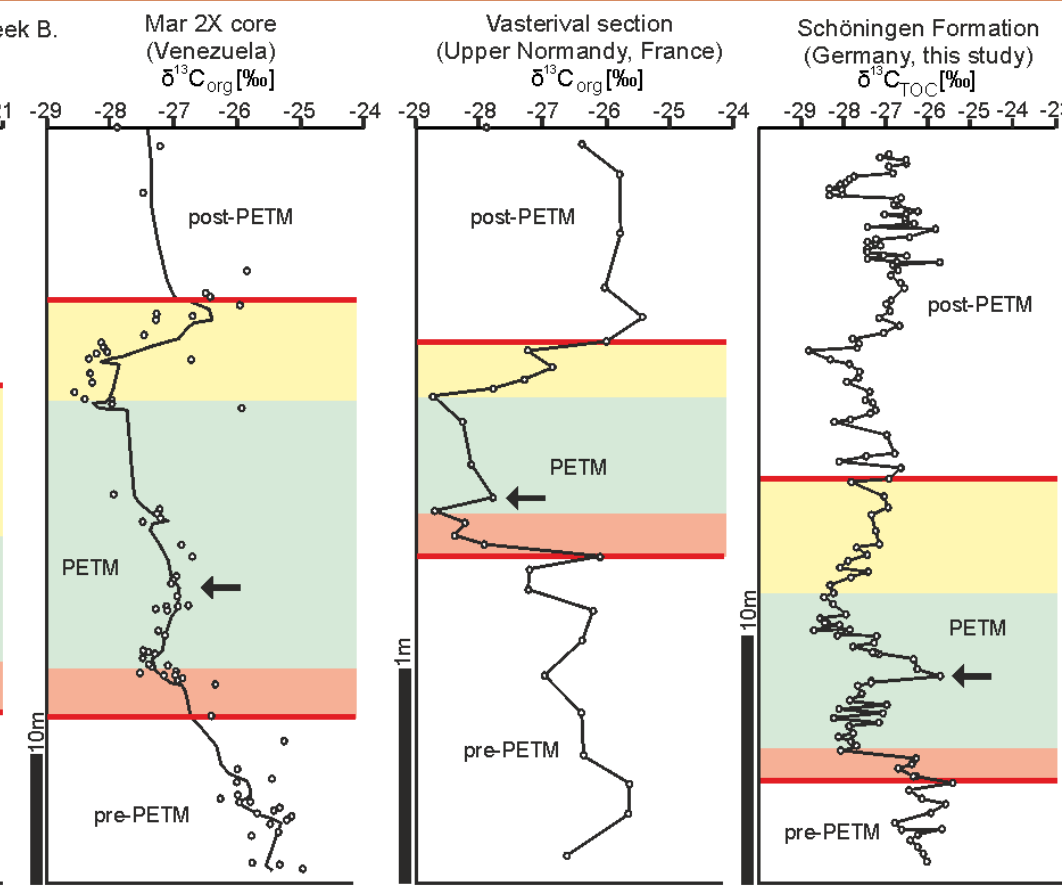

Beigou section
(Nanyang Basin, China)

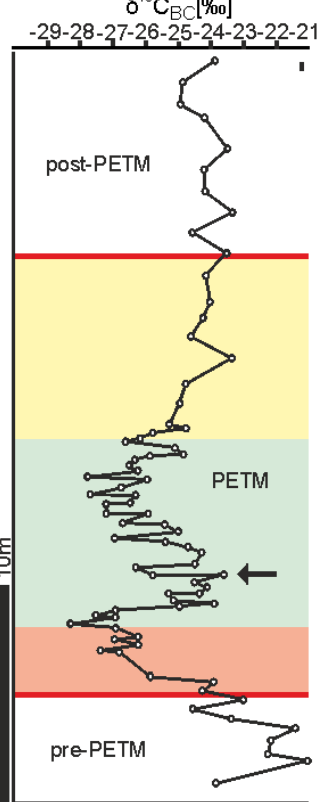




\section{S3 Data tables}

Tab. S1 Total organic carbon concentration (\%TOC) and carbon isotope data of bulk organics $\left(\delta^{13} \mathrm{C}_{\mathrm{TOC}}\right)$.

\begin{tabular}{|c|c|c|c|c|c|c|c|c|c|}
\hline & Sample & $\begin{array}{l}\text { strat. } \\
\text { position }\end{array}$ & $\delta^{13} \mathrm{C}$ & $\begin{array}{l}\text { TOC } \\
\text { (IRMS) }\end{array}$ & & Sample & $\begin{array}{l}\text { strat. } \\
\text { position }\end{array}$ & $\delta^{13} \mathrm{C}$ & $\begin{array}{l}\text { TOC } \\
\text { (IRMS) } \\
\end{array}$ \\
\hline & & [m] & [\%o ] & [\%] & & & {$[\mathrm{m}]$} & [\%o ] & [\%] \\
\hline \multirow{3}{*}{$\hat{\underline{\varphi}}$} & Schoe I 80a & 98.23 & -26.21 & 8.85 & \multirow{29}{*}{ 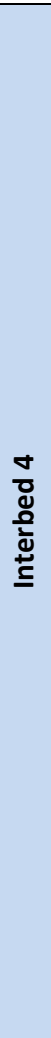 } & Schoe XIII 31 & 76.65 & -27.62 & 16.33 \\
\hline & Schoe I 78 & 98.15 & -26.44 & 6.13 & & Schoe XIII 30 & 76.48 & -27.68 & 2.21 \\
\hline & Schoe I 76c & 97.95 & -26.57 & 5.18 & & Schoe XIII 29e & 75.9 & -27.86 & 1.4 \\
\hline \multirow{8}{*}{ 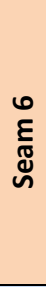 } & Schoe I 75d & 97.51 & -26.26 & 53.48 & & Schoe XIII 29d & 74.68 & -27.81 & 1.02 \\
\hline & Schoe I 75b & 97.25 & -26.22 & 59.4 & & Schoe XIII 29b & 73.08 & -27.48 & 0.72 \\
\hline & Schoe I 74 & 96.99 & -26.52 & 63.64 & & Schoe XIII 28c & 71.48 & -27.42 & 1.68 \\
\hline & Schoe I 73d & 96.83 & -26.45 & 60.66 & & Schoe XIII 28b & 70.74 & -27.63 & 1.44 \\
\hline & Schoe I 73b & 96.34 & -26.53 & 59.23 & & Schoe XIII 28a & 70.01 & -27.37 & 1.79 \\
\hline & Schoe I 72a & 95.71 & -26.74 & 59.24 & & Schoe XIII 27c & 69.28 & -27.53 & 4.64 \\
\hline & Schoe I 71b & 95.3 & -27.01 & 49.91 & & Schoe XIII 27b & 68.73 & -28.2 & 5.39 \\
\hline & Schoe I 71/2 & 95.06 & -26.37 & 60.62 & & Schoe XIII 27a & 68.18 & -27.56 & 5.11 \\
\hline \multirow{26}{*}{ 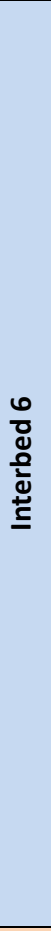 } & Schoe I 70 & 94.84 & -26.61 & 5.98 & & Schoe XIII 25 & 67.35 & -26.88 & 1.57 \\
\hline & Schoe I 68b & 94.58 & -26.39 & 3.35 & & Schoe XIII 23c & 66.51 & -27.14 & 2.92 \\
\hline & Schoe I 65 & 94.35 & -26.27 & 1.17 & & Schoe XIII 23b & 66.01 & -27.1 & 4.87 \\
\hline & Schoe I 63b & 94.03 & -26.5 & 0.46 & & Schoe XIII 23a & 65.51 & -27.34 & 7.28 \\
\hline & Schoe I 60b & 93.05 & -26.37 & 2.15 & & Schoe XIII 22 & 65.01 & -26.95 & 6.02 \\
\hline & Schoe I 58b & 92.38 & -26.65 & 9.86 & & Schoe XIII 20 & 64.57 & -27.12 & 2.59 \\
\hline & Schoe I 57b & 91.7 & -26.44 & 2.68 & & Schoe XIII 19 & 64.32 & -26.9 & 1.52 \\
\hline & Schoe 155 & 91.21 & -27.06 & 0.66 & & Schoe XIII 17 & 63.88 & -26.59 & 2.65 \\
\hline & Schoe I 53b & 91.02 & -27.16 & 1.18 & & Schoe XIII 16 & 63.19 & -26.71 & 0.75 \\
\hline & Schoe I 52c & 90.42 & -27.43 & 1.83 & & Schoe XIII 14a & 62.39 & -27.21 & 1.46 \\
\hline & Schoe I 51b & 89.87 & -27.19 & 0.92 & & Schoe XIII 10b & 61.57 & -27.03 & 3.32 \\
\hline & Schoe I 46b & 88.56 & -26.94 & 10.54 & & Schoe XIII 9e & 61.16 & -26.99 & 3.75 \\
\hline & Schoe I 45 & 88.25 & -26.6 & 7.5 & & Schoe XIII 9c & 60.44 & -27.19 & 7.03 \\
\hline & Schoe I 43 & 87.64 & -26.62 & 2.68 & & Schoe XIII 9a & 59.8 & -27.39 & 6.12 \\
\hline & Schoe I 41 & 87.05 & -26.95 & 2.05 & & Schoe XIII 8c & 59.2 & -27.27 & 2.73 \\
\hline & Schoe I 39 & 86.83 & -27.27 & 2.53 & & Schoe XIII 8a & 58.4 & -27.16 & 2.21 \\
\hline & Schoe I 37b & 86.32 & -27.04 & 4.31 & & Schoe XIII 6 & 58.02 & -27.07 & 1.14 \\
\hline & Schoe I 34 & 85.99 & -26.79 & 40.94 & & Schoe XXV 39 & 56.78 & -27.41 & 14.14 \\
\hline & Schoe I 32a & 85.53 & -27.38 & 5.16 & \multirow{5}{*}{$\begin{array}{l}m \\
\frac{E}{\mathbb{D}} \\
\stackrel{్}{ }\end{array}$} & Schoe XXV 37 & 56.49 & -26.91 & 52.63 \\
\hline & Schoe I 30a & 84.98 & -27.39 & 3.03 & & Schoe XXV 36c & 56.18 & -27.4 & 69.2 \\
\hline & Schoe I 28 & 84.64 & -27.4 & 1.85 & & Schoe XXV 36b & 56 & -27.37 & 68.77 \\
\hline & Schoe I 27 & 84.58 & -27.28 & 2.68 & & Schoe XXV 36a & 55.9 & -27.41 & 48.8 \\
\hline & Schoe I 25b & 84.1 & -27.72 & 1.34 & & Schoe XXV 35 & 55.81 & -27.48 & 61.25 \\
\hline & Schoe I 24b & 83.53 & -27.72 & 8.16 & \multirow{18}{*}{$\begin{array}{l}m \\
\text { m } \\
\mathbb{d} \\
\frac{0}{2} \\
\stackrel{ \pm}{\leq}\end{array}$} & Schoe XXV 34 & 55.46 & -27.06 & 14.03 \\
\hline & Schoe I 22 & 83.11 & -27.44 & 7.2 & & Schoe XXV 33 & 55.08 & -27.07 & 14.97 \\
\hline & Schoe I 21 & 83.01 & -27.06 & 12.19 & & Schoe XXV 31 & 54.43 & -26.91 & 10.59 \\
\hline \multirow{6}{*}{ 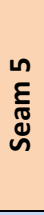 } & Schoe I 20c & 82.89 & -26.76 & 55.1 & & Schoe XXV 29a & 53.59 & -27.01 & 6.13 \\
\hline & Schoe I 20a & 82.49 & -26.71 & 56.6 & & Schoe XXV 28a & 53 & -26.95 & 3.64 \\
\hline & Schoe I 19 & 82.31 & -26.73 & 12.08 & & Schoe XXV 27b & 52.1 & -27.61 & 9.52 \\
\hline & Schoe I 17 & 82.18 & -26.46 & 59.3 & & Schoe XXV 24 & 50.1 & -26.84 & 6.96 \\
\hline & Schoe I 16b & 82.14 & -26.5 & 55.82 & & Schoe XXV 21b & 49.24 & -27.01 & 12.68 \\
\hline & Schoe I 16a & 82.03 & -26.17 & 56.79 & & Schoe XXV 19a & 48.52 & -26.89 & 5.85 \\
\hline \multirow{13}{*}{ 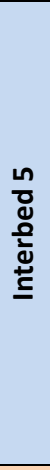 } & Schoe I 14d & 81.8 & -26.64 & 3.32 & & Schoe XXV 16c & 47.48 & -27.09 & 3.47 \\
\hline & Schoe I 14b & 81.41 & -26.55 & 0.09 & & Schoe XXV 15 & 46.12 & -27.6 & 12.68 \\
\hline & Schoe I 13b & 81.05 & -26.59 & 0.17 & & Schoe XXV 13 & 45.34 & -26.88 & 5.1 \\
\hline & Schoe I 12 & 80.15 & -26.55 & 1.2 & & Schoe XXV 11 & 44.53 & -27.7 & 11.7 \\
\hline & Schoe I 10 & 79.9 & -26.64 & 5.42 & & Schoe XXV 8 & 43.16 & -27.51 & 7.97 \\
\hline & Schoe 18 & 79.29 & -26.43 & 4.61 & & Schoe XXV 6 & 42.22 & -27.79 & 7.28 \\
\hline & Schoe I 7b & 78.87 & -26.21 & 0.81 & & Schoe XXV 4 & 41.9 & -27.38 & 12.28 \\
\hline & Schoe I 6a & 78.53 & -26.25 & 3.52 & & Schoe XXV 2 & 41.35 & -26.88 & 0.08 \\
\hline & Schoe I 4b & 78.05 & -26.1 & 5.28 & & Schoe VI 24 & 41.24 & -26.8 & 12.6 \\
\hline & Schoe I 3b & 77.79 & -27.02 & 5.24 & \multirow{9}{*}{ 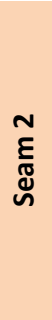 } & Schoe XXV 1 & 41.14 & -26.25 & 64.74 \\
\hline & Schoe I 2 & 77.56 & -26.74 & 14.36 & & Schoe VI 22b & 40.65 & -25.9 & 60.2 \\
\hline & Schoe I 1b & 77.51 & -26.7 & 22.7 & & Schoe VI 22a & 40.53 & -26.2 & 61 \\
\hline & Schoe XIII 37 & 77.31 & -28.16 & 35.54 & & Schoe VI 21 & 40.47 & -26.4 & 61.6 \\
\hline \multirow{5}{*}{ 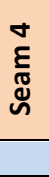 } & Schoe XIII 36 & 77.21 & -27.36 & 52.73 & & Schoe VI 20 & 40.33 & -26.3 & 61 \\
\hline & Schoe XIII 35 & 77.16 & -26.85 & 52.25 & & Schoe VI 19 & 40.25 & -26.4 & 59.6 \\
\hline & Schoe XIII 34 & 77.02 & -26.8 & 49.09 & & Schoe VI 18c & 40.1 & -25.8 & 63.9 \\
\hline & Schoe XIII 33 & 76.9 & -27.49 & 21.63 & & Schoe VI 18b & 40.02 & -26.7 & 63.7 \\
\hline & Schoe XIII 32 & 76.83 & -27.95 & 20.85 & & Schoe VI 18a & 39.92 & -26.7 & 62.3 \\
\hline
\end{tabular}




\begin{tabular}{|c|c|c|c|c|}
\hline & Sample & $\begin{array}{c}\text { strat. } \\
\text { position }\end{array}$ & $\delta^{13} \mathrm{C}$ & $\begin{array}{c}\text { TOC } \\
\text { (IRMS) }\end{array}$ \\
\hline & & [m] & [\%o] & [\%] \\
\hline \multirow{33}{*}{ 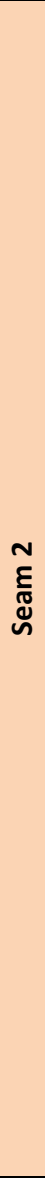 } & Schoe VI 17b & 39.77 & -25.7 & 63.2 \\
\hline & Schoe VI 17a & 39.61 & -26 & 62.9 \\
\hline & Schoe VI 16 & 39.59 & -25.1 & 66.4 \\
\hline & Schoe VI $15 f$ & 39.5 & -25.8 & 65.5 \\
\hline & Schoe VI 15e & 39.3 & -26.7 & 63.4 \\
\hline & Schoe VI 15d & 39 & -26.1 & 61.9 \\
\hline & Schoe VI 15c & 38.7 & -26.6 & 63.1 \\
\hline & Schoe VI 15b & 38.4 & -26.1 & 63.1 \\
\hline & Schoe VI 15a & 38 & -26.2 & 65.9 \\
\hline & Schoe VI 14 & 37.83 & -26.5 & 65 \\
\hline & Schoe VI 13 & 37.82 & -27.4 & 67.3 \\
\hline & Schoe VI 12 & 37.66 & -27.7 & 68.1 \\
\hline & Schoe VI 11c & 37.59 & -26.5 & 63.8 \\
\hline & Schoe VI 11b & 37.49 & -26.5 & 62.6 \\
\hline & Schoe VI 11a & 37.41 & -28.3 & 67.7 \\
\hline & Schoe VI 10b & 37.3 & -27.1 & 66 \\
\hline & Schoe VI 10a & 37.22 & -27.6 & 68.4 \\
\hline & Schoe VI 9c & 37.19 & -27.4 & 68.2 \\
\hline & Schoe VI 9b & 37.11 & -28.1 & 55 \\
\hline & Schoe VI 9a & 36.96 & -27.9 & 63.3 \\
\hline & Schoe VI 8b & 36.86 & -27.5 & 59.2 \\
\hline & Schoe VI 8a & 36.7 & -27.5 & 56 \\
\hline & Schoe VI 7d & 36.6 & -27.6 & 60.2 \\
\hline & Schoe VI 7c & 36.5 & -28 & 60.9 \\
\hline & Schoe VI 7b & 36.4 & -27.7 & 59.9 \\
\hline & Schoe VI 7a & 36.3 & -27.6 & 60.4 \\
\hline & Schoe VI 6 & 36.2 & -27.4 & 58.9 \\
\hline & Schoe VI 5b & 36.14 & -27.8 & 50 \\
\hline & Schoe VI 5a & 36.05 & -27.8 & 56.7 \\
\hline & Schoe VI 4b & 35.92 & -27.8 & 59.8 \\
\hline & Schoe VI 4a & 35.87 & -27.9 & 52.9 \\
\hline & Schoe VI 3b & 35.73 & -27.9 & 56.9 \\
\hline & Schoe VI 3a & 35.65 & -27.9 & 55.8 \\
\hline \multirow{33}{*}{ 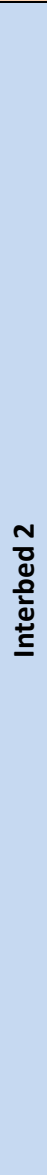 } & Schoe VI 2 & 35.55 & -28.1 & 39.8 \\
\hline & Schoe VI 1 & 35.53 & -26.8 & 19.7 \\
\hline & Schoe V 34b & 35.5 & -27.1 & 15.7 \\
\hline & Schoe V 34a & 35.45 & -27.9 & 14.5 \\
\hline & Schoe V 33 & 35.35 & -27.3 & 27 \\
\hline & Schoe V 32 & 35.29 & -27.3 & 8.9 \\
\hline & Schoe V 31 & 35.17 & -27.1 & 7 \\
\hline & Schoe V 30 & 35.07 & -27 & 3.1 \\
\hline & Schoe V 29 & 34.96 & -26.8 & 0.2 \\
\hline & Schoe V 27b & 34.89 & -26.8 & 0.3 \\
\hline & Schoe V 27a & 34.7 & -27.1 & 1.6 \\
\hline & Schoe V 26b & 34.53 & -27 & 0.8 \\
\hline & Schoe V 26a & 34.4 & -26.9 & 0.5 \\
\hline & Schoe V 25b & 34.2 & -26.7 & 0.2 \\
\hline & Schoe V 25a & 34 & -26.9 & 0.2 \\
\hline & Schoe V 24 & 33.87 & -27.2 & 5.2 \\
\hline & Schoe V 23c & 33.78 & -27 & 0.6 \\
\hline & Schoe V 23b & 33.6 & -27.1 & 4 \\
\hline & Schoe V 23a & 33.5 & -27 & 0.6 \\
\hline & Schoe V 22b & 33.45 & -27 & 3.6 \\
\hline & Schoe V 22a & 33.3 & -27.1 & 3.7 \\
\hline & Schoe V 21b & 33.16 & -27.1 & 2.5 \\
\hline & Schoe V 21a & 32.95 & -27.1 & 2.8 \\
\hline & Schoe V 20b & 32.83 & -27.1 & 4.8 \\
\hline & Schoe V 20a & 32.5 & -27 & 3.8 \\
\hline & Schoe V 19b & 32.39 & -27 & 3.1 \\
\hline & Schoe V 19a & 32.15 & -26.9 & 1.4 \\
\hline & Schoe V 18b & 31.99 & -27 & 1.5 \\
\hline & Schoe V 18a & 31.76 & -27 & 1.3 \\
\hline & Schoe V 17b & 31.62 & -27 & 4.4 \\
\hline & Schoe V 17a & 31.4 & -26.9 & 5.3 \\
\hline & Schoe V 16 & 31.3 & -26.9 & 7.2 \\
\hline & Schoe V 15 & 31.15 & -27.1 & 4.5 \\
\hline
\end{tabular}

\begin{tabular}{|c|c|c|c|c|}
\hline & Sample & $\begin{array}{l}\text { strat. } \\
\text { position }\end{array}$ & $\delta^{13} \mathrm{C}$ & $\begin{array}{l}\text { TOC } \\
\text { (IRMS) }\end{array}$ \\
\hline & & {$[\mathrm{m}]$} & [\%o ] & [\%] \\
\hline \multirow{12}{*}{ 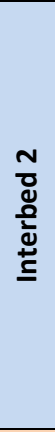 } & Schoe V 14 & 31.03 & -27 & 7.3 \\
\hline & Schoe V 13 & 30.94 & -26.8 & 4.3 \\
\hline & Schoe V 12c & 30.23 & -26.9 & 8.8 \\
\hline & Schoe V 11 & 29.61 & -26.9 & 9.4 \\
\hline & Schoe V 10a & 29.4 & -27.1 & 8.7 \\
\hline & Schoe V 9 & 29.3 & -26.5 & 8.1 \\
\hline & Schoe V 8 & 29.17 & -26.5 & 2.7 \\
\hline & Schoe V 7b & 29.02 & -26.9 & 4.4 \\
\hline & Schoe V 7a & 28.79 & -26.8 & 3.7 \\
\hline & Schoe V 6 & 28.65 & -27.7 & 4.1 \\
\hline & Schoe V 5 & 28.54 & -27.8 & 7.3 \\
\hline & Schoe V 4 & 28.4 & -27.9 & 9.7 \\
\hline \multirow{28}{*}{$\begin{array}{l}\text {-1 } \\
\stackrel{\varepsilon}{\mathbb{D}} \\
\text { ద }\end{array}$} & Schoe V 2 & 28.18 & -28.3 & 52.8 \\
\hline & Schoe V 1 & 28.14 & -28.1 & 64.4 \\
\hline & Schoe IX 58b & 28.03 & -28 & 54.7 \\
\hline & Schoe IX 58a & 27.93 & -28 & 59.5 \\
\hline & Schoe IX 57b & 27.82 & -28.3 & 61.1 \\
\hline & Schoe IX 57a & 27.74 & -26.6 & 66.5 \\
\hline & Schoe IX 56b & 27.63 & -26.7 & 66 \\
\hline & Schoe IX 56a & 27.51 & -26.8 & 62 \\
\hline & Schoe IX 55b & 27.4 & -26.7 & 66 \\
\hline & Schoe IX 55a & 27.31 & -26.5 & 65.2 \\
\hline & Schoe IX 54b & 27.2 & -26.2 & 66.6 \\
\hline & Schoe IX 54a & 27.1 & -26.5 & 64.7 \\
\hline & Schoe IX 53d & 26.99 & -27 & 67.2 \\
\hline & Schoe IX 53c & 26.87 & -26.5 & 68.2 \\
\hline & Schoe IX 53b & 26.72 & -26.5 & 66.8 \\
\hline & Schoe IX 53a & 26.57 & -26.3 & 64.9 \\
\hline & Schoe IX 52d & 26.47 & -27.4 & 63.2 \\
\hline & Schoe IX 52c & 26.38 & -25.8 & 67 \\
\hline & Schoe IX 52b & 26.18 & -26.4 & 66.7 \\
\hline & Schoe IX 52a & 26.02 & -27.2 & 61.1 \\
\hline & Schoe IX 51b & 25.92 & -27.4 & 58.8 \\
\hline & Schoe IX 51a & 25.82 & -27.2 & 57.8 \\
\hline & Schoe IX 50b & 25.71 & -27.1 & 58.8 \\
\hline & Schoe IX 50a & 25.61 & -27.4 & 62.1 \\
\hline & Schoe IX 49b & 25.51 & -27.4 & 63.1 \\
\hline & Schoe IX 49a & 25.42 & -26.5 & 58.7 \\
\hline & Schoe IX 48b & 25.32 & -27 & 58.8 \\
\hline & Schoe IX 48a & 25.23 & -27.4 & 57.5 \\
\hline \multirow{26}{*}{ 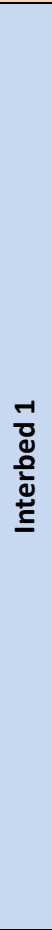 } & Schoe IX 47b & 25.16 & -26.7 & 46.9 \\
\hline & Schoe IX 47a & 25.08 & -25.7 & 26.5 \\
\hline & Schoe IX 46 & 24.89 & -26.8 & 6.9 \\
\hline & Schoe IX 45c & 24.73 & -26.69 & 4.97 \\
\hline & Schoe IX 45a & 24.45 & -26.85 & 4.5 \\
\hline & Schoe IX 44a & 24.14 & -26.62 & 7.64 \\
\hline & Schoe IX 42 & 23.89 & -26.56 & 7.09 \\
\hline & Schoe IX 40d & 23.48 & -26.83 & 1.41 \\
\hline & Schoe IX 40c & 23.23 & -26.96 & 2.13 \\
\hline & Schoe IX 40b & 22.98 & -26.87 & 1.77 \\
\hline & Schoe IX 40a & 22.73 & -27.1 & 2.79 \\
\hline & Schoe IX 39 & 22.39 & -26.66 & 2.66 \\
\hline & Schoe IX 38 & 22.09 & -27.02 & 2.14 \\
\hline & Schoe IX 37 & 21.87 & -27.75 & 2.27 \\
\hline & Schoe IX 36b & 21.68 & -27.61 & 1.63 \\
\hline & Schoe IX 36a & 21.52 & -27.65 & 1.35 \\
\hline & Schoe IX 35 & 21.33 & -28.8 & 2.32 \\
\hline & Schoe IX 33 & 20.98 & -28.28 & 1.79 \\
\hline & Schoe IX 32 & 20.79 & -27.82 & 0.9 \\
\hline & Schoe IX 31b & 20.48 & -27.59 & 1.52 \\
\hline & Schoe IX 30 & 20.17 & -27.6 & 1.45 \\
\hline & Schoe IX 29b & 19.98 & -27.88 & 1.74 \\
\hline & Schoe IX 28b & 19.65 & -27.34 & 1.08 \\
\hline & Schoe IX 27b & 19.27 & -27.43 & 1.26 \\
\hline & Schoe IX 27a & 19.09 & -27.27 & 1.46 \\
\hline & Schoe IX 26b & 18.85 & -27.21 & 1.45 \\
\hline
\end{tabular}




\begin{tabular}{|c|c|c|c|c|}
\hline & Sample & $\begin{array}{c}\text { strat. } \\
\text { position }\end{array}$ & $\delta^{13} \mathrm{C}$ & $\begin{array}{c}\text { TOC } \\
\text { (IRMS) }\end{array}$ \\
\hline & & [m] & [\%o ] & [\%] \\
\hline \multirow{30}{*}{ 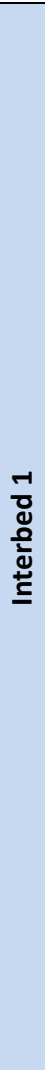 } & Schoe IX 26a & 18.74 & -27.33 & 1.93 \\
\hline & Schoe IX 25a & 18.49 & -27.81 & 0.12 \\
\hline & Schoe IX 23d & 18.35 & -28.19 & 0.26 \\
\hline & Schoe IX 23a & 17.77 & -26.94 & 0.08 \\
\hline & Schoe IX 22a & 17.02 & -26.76 & 0.1 \\
\hline & Schoe IX 21 & 16.89 & -27.44 & 0.11 \\
\hline & Schoe IX 20 & 16.74 & -28.07 & 0.14 \\
\hline & Schoe IX 19b & 16.46 & -26.62 & 0.1 \\
\hline & Schoe IX 19a & 16.12 & -26.9 & 0.08 \\
\hline & Schoe IX 18d & 15.9 & -27.79 & 0.1 \\
\hline & Schoe IX 18a & 15.28 & -27.01 & 0.06 \\
\hline & Schoe IX 17a & 14.87 & -26.92 & 0.08 \\
\hline & Schoe IX 16b & 14.5 & -27.3 & 0.05 \\
\hline & Schoe IX 15b & 14 & -27.21 & 0.07 \\
\hline & Schoe IX 14b & 13.46 & -27.13 & 0.09 \\
\hline & Schoe IX 14a & 13.26 & -27.66 & 0.09 \\
\hline & Schoe IX 12b & 12.91 & -27.41 & 0.03 \\
\hline & Schoe IX 12a & 12.71 & -27.86 & 0.14 \\
\hline & Schoe IX 11a & 12.39 & -28.05 & 0.12 \\
\hline & Schoe IX 10b & 12.2 & -27.39 & 0.05 \\
\hline & Schoe IX 10a & 11.99 & -27.8 & 0.14 \\
\hline & Schoe IX 8b & 11.73 & -28.28 & 1.21 \\
\hline & Schoe IX 6d & 11.38 & -28.21 & 0.63 \\
\hline & Schoe IX 6c & 11.21 & -28.42 & 0.55 \\
\hline & Schoe IX 6b & 10.91 & -28.2 & 0.33 \\
\hline & Schoe IX 5b & 10.42 & -27.9 & 0.1 \\
\hline & Schoe IX 5a & 10.34 & -28.52 & 2.37 \\
\hline & Schoe IX 3c & 10.11 & -28.42 & 1.08 \\
\hline & Schoe IX 3a & 10.01 & -28.43 & 1.45 \\
\hline & Schoe XLIX/29 & 10 & -28.35 & 2.05 \\
\hline \multirow{36}{*}{ 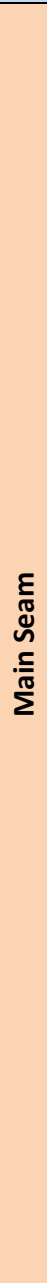 } & Schoe XLIX/28 & 9.92 & -28.04 & 53.38 \\
\hline & Schoe IX 1b & 9.85 & -28.67 & 64.62 \\
\hline & Schoe XLIX/27b & 9.77 & -27.81 & 58.37 \\
\hline & Schoe IX 1a & 9.6 & -28.12 & 64.56 \\
\hline & Schoe XLIX/27a & 9.51 & -27.20 & 50.03 \\
\hline & Schoe XLIX/26 & 9.28 & -27.26 & 48.69 \\
\hline & Schoe XLIX/25 & 9.09 & -27.74 & 42.43 \\
\hline & Schoe XLIX/24 & 8.95 & -27.28 & 60.81 \\
\hline & Schoe XLIX/23 & 8.83 & -27.20 & 56.59 \\
\hline & Schoe XLIX/22 & 8.73 & -27.13 & 43.55 \\
\hline & Schoe XLIX/21d & 8.62 & -26.29 & 58.44 \\
\hline & Schoe XLIX/21c & 8.17 & -26.23 & 59.22 \\
\hline & Schoe XLIX/21b & 7.97 & -25.69 & 58.8 \\
\hline & Schoe XLIX/21a & 7.67 & -27.31 & 63.53 \\
\hline & Schoe XLIX/20 & 7.43 & -27.62 & 56.42 \\
\hline & Schoe XLIX/19 & 7.15 & -27.54 & 62.01 \\
\hline & Schoe XLIX/18 & 6.92 & -27.84 & 58.67 \\
\hline & Schoe XLIX/17 & 6.75 & -26.96 & 61.41 \\
\hline & Schoe XLIX/16b & 6.51 & -28.06 & 23.23 \\
\hline & Schoe XLIX/16a & 6.31 & -27.06 & 56.49 \\
\hline & Schoe XLIX/15 & 6.13 & -28.23 & 57.88 \\
\hline & Schoe XLIX/14 & 6 & -27.12 & 52.64 \\
\hline & Schoe XLIX/13 & 5.8 & -27.84 & 55.95 \\
\hline & Schoe XLIX/12 & 5.58 & -27.74 & 43.76 \\
\hline & Schoe XLIX/11 & 5.37 & -28.09 & 60.01 \\
\hline & Schoe XLIX/10 & 5.2 & -27.79 & 48.51 \\
\hline & Schoe XLIX/9 & 5.02 & -27.67 & 48.23 \\
\hline & Schoe XLIX/8 & 4.79 & -28.03 & 33.86 \\
\hline & Schoe XLIX/7 & 4.57 & -26.27 & 59.18 \\
\hline & Schoe XLIX/6b & 4.27 & -26.36 & 61.38 \\
\hline & Schoe XLIX/6a & 4.02 & -26.68 & 57.31 \\
\hline & Schoe XLIX/5 & 3.8 & -26.32 & 43.56 \\
\hline & Schoe XLIX/4d & 3.76 & -26.26 & 59.49 \\
\hline & Schoe XLIX/4c & 3.53 & -25.4 & 60.72 \\
\hline & Schoe XLIX/4b & 3.23 & -26.42 & 60.11 \\
\hline & Schoe XLIX/4a & 2.93 & -26.12 & 62.38 \\
\hline
\end{tabular}

\begin{tabular}{|c|c|c|c|c|}
\hline & Sample & $\begin{array}{l}\text { strat. } \\
\text { position }\end{array}$ & $\delta^{13} \mathrm{C}$ & $\begin{array}{l}\text { TOC } \\
\text { (IRMS) }\end{array}$ \\
\hline & & [m] & [\%o ] & [\%] \\
\hline \multirow{11}{*}{ 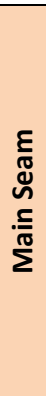 } & Schoe XLIX/3d & 2.61 & -25.55 & 59.35 \\
\hline & Schoe XLIX/3c & 2.28 & -25.9 & 60.71 \\
\hline & Schoe XLIX/3b & 1.88 & -26.75 & 63.08 \\
\hline & Schoe XLIX/3a & 1.55 & -26.6 & 59.99 \\
\hline & Schoe XLIX/2b & 1.51 & -25.65 & 40.55 \\
\hline & Schoe XLIX/2a & 1.47 & -26.21 & 54.77 \\
\hline & Schoe XLIX/1e & 1.35 & -26.21 & 61.01 \\
\hline & Schoe XLIX/1d & 1.05 & -26.4 & 59.45 \\
\hline & Schoe XLIX/1c & 0.75 & -26.2 & 60.28 \\
\hline & Schoe XLIX/1b & 0.45 & -26.07 & 60.32 \\
\hline & Schoe XLIX/1a & 0.15 & -25.99 & 56.49 \\
\hline
\end{tabular}


Tab. S2 Palynological data of the Main Seam (raw data).

\begin{tabular}{|c|c|c|c|c|c|c|c|c|c|c|c|c|c|c|c|c|}
\hline $\begin{array}{c}\mathrm{m} \\
\text { above } \\
\text { base } \\
\text { Main } \\
\text { Seam }\end{array}$ & 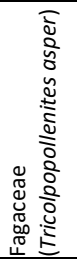 & 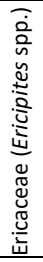 & 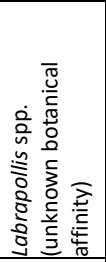 & 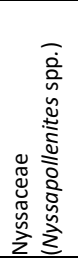 & 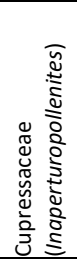 & 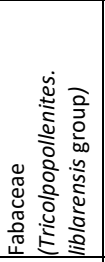 & 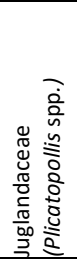 & 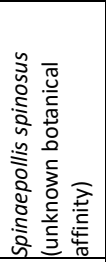 & 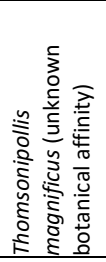 & 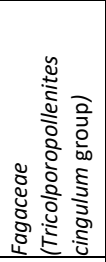 & 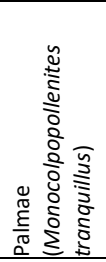 & 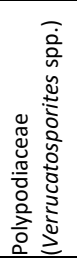 & 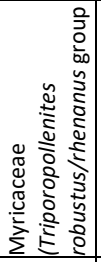 & 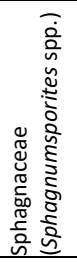 & 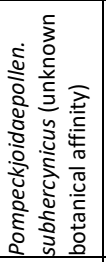 & 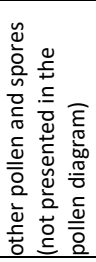 \\
\hline 11.05 & 0 & 0 & 3 & 10 & 16 & 83 & 16 & 0 & 17 & 7 & 8 & 1 & 48 & 1 & 51 & 237 \\
\hline 10.98 & 0 & 0 & 2 & 8 & 5 & 61 & 9 & 1 & 12 & 8 & 3 & 0 & 49 & 2 & 19 & 128 \\
\hline 10.87 & 0 & 0 & 0 & 19 & 22 & 3 & 9 & 1 & 0 & 2 & 0 & 2 & 98 & 21 & 34 & 89 \\
\hline 10.78 & 0 & 0 & 2 & 22 & 44 & 7 & 16 & 0 & 0 & 1 & 0 & 3 & 47 & 2 & 42 & 116 \\
\hline 10.70 & 0 & 0 & 2 & 16 & 30 & 12 & 6 & 3 & 0 & 4 & 6 & 3 & 43 & 3 & 40 & 132 \\
\hline 10.59 & 3 & 0 & 0 & 15 & 11 & 13 & 6 & 10 & 1 & 2 & 18 & 8 & 102 & 0 & 4 & 106 \\
\hline 10.50 & 0 & 0 & 1 & 3 & 16 & 8 & 8 & 0 & 0 & 4 & 5 & 0 & 100 & 11 & 18 & 127 \\
\hline 10.34 & 0 & 0 & 0 & 3 & 6 & 12 & 4 & 0 & 0 & 3 & 6 & 4 & 134 & 14 & 8 & 106 \\
\hline 10.21 & 0 & 0 & 5 & 7 & 23 & 12 & 12 & 0 & 2 & 15 & 0 & 23 & 34 & 25 & 4 & 144 \\
\hline 10.11 & 0 & 3 & 2 & 12 & 44 & 4 & 7 & 2 & 7 & 7 & 4 & 4 & 49 & 8 & 48 & 102 \\
\hline 9.52 & 0 & 1 & 2 & 9 & 53 & 13 & 8 & 0 & 7 & 13 & 1 & 2 & 51 & 0 & 64 & 76 \\
\hline 9.41 & 0 & 0 & 2 & 7 & 71 & 12 & 15 & 2 & 1 & 8 & 1 & 3 & 44 & 2 & 40 & 94 \\
\hline 9.32 & 0 & 0 & 0 & 6 & 21 & 6 & 2 & 0 & 2 & 3 & 1 & 1 & 1 & 27 & 24 & 206 \\
\hline 9.19 & 0 & 0 & 0 & 3 & 8 & 13 & 6 & 0 & 0 & 4 & 0 & 0 & 6 & 14 & 160 & 91 \\
\hline 9.06 & 0 & 0 & 1 & 2 & 11 & 7 & 4 & 1 & 0 & 7 & 0 & 0 & 19 & 73 & 97 & 90 \\
\hline 8.90 & 0 & 0 & 1 & 0 & 3 & 1 & 4 & 0 & 0 & 1 & 0 & 2 & 22 & 19 & 172 & 75 \\
\hline 8.77 & 2 & 1 & 3 & 6 & 3 & 11 & 2 & 0 & 1 & 0 & 1 & 0 & 47 & 9 & 157 & 57 \\
\hline 8.67 & 1 & 0 & 0 & 3 & 23 & 6 & 7 & 0 & 0 & 12 & 1 & 0 & 30 & 30 & 65 & 133 \\
\hline 8.37 & 0 & 0 & 0 & 2 & 13 & 5 & 10 & 0 & 0 & 14 & 0 & 0 & 59 & 33 & 109 & 56 \\
\hline 8.23 & 0 & 0 & 0 & 3 & 17 & 9 & 6 & 0 & 0 & 13 & 0 & 0 & 49 & 17 & 123 & 63 \\
\hline 8.13 & 0 & 1 & 3 & 1 & 5 & 12 & 2 & 1 & 0 & 3 & 1 & 0 & 69 & 112 & 38 & 52 \\
\hline 7.98 & 0 & 0 & 9 & 10 & 35 & 30 & 14 & 2 & 1 & 12 & 2 & 1 & 25 & 58 & 31 & 70 \\
\hline 7.86 & 1 & 0 & 7 & 8 & 96 & 47 & 13 & 7 & 1 & 11 & 0 & 1 & 5 & 2 & 2 & 99 \\
\hline 7.82 & 0 & 0 & 7 & 8 & 123 & 17 & 12 & 7 & 0 & 15 & 1 & 3 & 0 & 1 & 2 & 104 \\
\hline 7.77 & 1 & 0 & 13 & 19 & 59 & 51 & 22 & 11 & 0 & 10 & 0 & 2 & 3 & 2 & 1 & 106 \\
\hline 7.73 & 1 & 0 & 12 & 12 & 24 & 36 & 17 & 9 & 3 & 9 & 3 & 4 & 7 & 0 & 1 & 165 \\
\hline 7.70 & 3 & 0 & 12 & 20 & 47 & 34 & 29 & 9 & 0 & 8 & 3 & 5 & 8 & 2 & 2 & 138 \\
\hline 7.62 & 0 & 0 & 10 & 50 & 47 & 21 & 14 & 3 & 5 & 24 & 1 & 2 & 11 & 2 & 1 & 116 \\
\hline 7.52 & 1 & 1 & 7 & 15 & 12 & 34 & 6 & 6 & 2 & 1 & 0 & 1 & 40 & 2 & 11 & 162 \\
\hline 7.39 & 1 & 0 & 1 & 8 & 17 & 53 & 15 & 4 & 0 & 1 & 1 & 0 & 10 & 2 & 2 & 187 \\
\hline 7.34 & 0 & 0 & 1 & 8 & 3 & 68 & 9 & 11 & 0 & 96 & 0 & 0 & 26 & 3 & 4 & 71 \\
\hline 7.31 & 1 & 0 & 2 & 15 & 21 & 28 & 11 & 11 & 0 & 46 & 3 & 2 & 43 & 11 & 2 & 105 \\
\hline 7.25 & 0 & 0 & 1 & 18 & 29 & 45 & 9 & 7 & 4 & 48 & 0 & 2 & 45 & 0 & 1 & 92 \\
\hline 7.19 & 0 & 0 & 0 & 30 & 43 & 22 & 15 & 20 & 3 & 29 & 4 & 0 & 38 & 0 & 0 & 101 \\
\hline 7.15 & 0 & 0 & 1 & 19 & 40 & 74 & 9 & 7 & 2 & 43 & 1 & 0 & 10 & 0 & 0 & 95 \\
\hline 7.09 & 2 & 1 & 1 & 37 & 18 & 103 & 7 & 7 & 3 & 4 & 8 & 1 & 12 & 1 & 0 & 101 \\
\hline 6.98 & 0 & 1 & 0 & 22 & 26 & 40 & 9 & 3 & 0 & 57 & 23 & 1 & 6 & 0 & 0 & 117 \\
\hline 6.88 & 0 & 1 & 1 & 22 & 29 & 46 & 11 & 1 & 9 & 17 & 22 & 0 & 62 & 0 & 0 & 140 \\
\hline 6.76 & 0 & 0 & 0 & 1 & 20 & 4 & 9 & 0 & 2 & 10 & 2 & 0 & 198 & 0 & 0 & 55 \\
\hline 6.66 & 0 & 1 & 1 & 32 & 17 & 39 & 8 & 4 & 7 & 43 & 4 & 1 & 72 & 1 & 0 & 79 \\
\hline 6.58 & 0 & 0 & 0 & 35 & 46 & 35 & 4 & 4 & 10 & 46 & 4 & 0 & 16 & 0 & 1 & 100 \\
\hline 6.47 & 0 & 0 & 3 & 2 & 11 & 11 & 5 & 0 & 0 & 3 & 4 & 0 & 99 & 3 & 1 & 160 \\
\hline 6.34 & 0 & 1 & 0 & 22 & 63 & 18 & 20 & 13 & 25 & 25 & 2 & 0 & 15 & 2 & 1 & 95 \\
\hline 6.29 & 0 & 0 & 2 & 29 & 45 & 27 & 4 & 25 & 23 & 9 & 2 & 4 & 4 & 3 & 3 & 120 \\
\hline 6.26 & 0 & 1 & 0 & 22 & 114 & 16 & 10 & 10 & 17 & 13 & 0 & 2 & 24 & 0 & 0 & 76 \\
\hline 6.21 & 0 & 0 & 1 & 16 & 83 & 17 & 6 & 23 & 12 & 12 & 7 & 0 & 40 & 0 & 0 & 83 \\
\hline 6.15 & 0 & 0 & 0 & 13 & 120 & 15 & 6 & 3 & 7 & 31 & 2 & 0 & 35 & 0 & 0 & 68 \\
\hline 6.09 & 0 & 0 & 0 & 10 & 67 & 12 & 8 & 3 & 2 & 11 & 6 & 0 & 126 & 1 & 0 & 55 \\
\hline
\end{tabular}




\begin{tabular}{|c|c|c|c|c|c|c|c|c|c|c|c|c|c|c|c|c|}
\hline $\begin{array}{c}m \\
\text { above } \\
\text { base } \\
\text { Main } \\
\text { Seam }\end{array}$ & 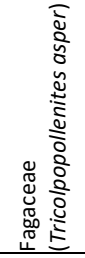 & 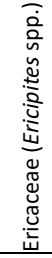 & 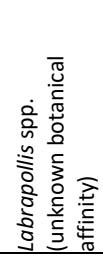 & 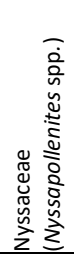 & 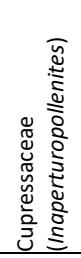 & 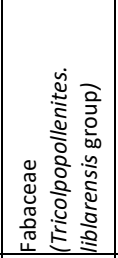 & 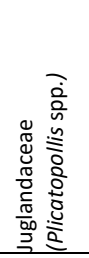 & 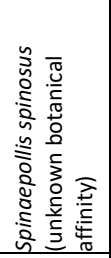 & 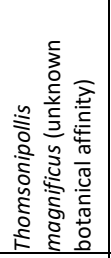 & 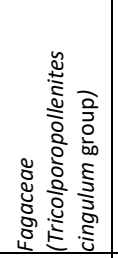 & 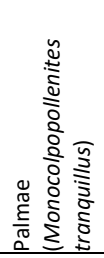 & 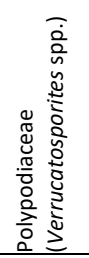 & 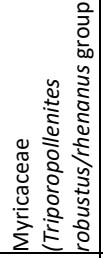 & 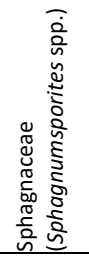 & 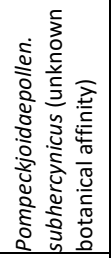 & 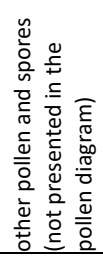 \\
\hline 5.99 & 2 & 0 & 5 & 7 & 39 & 46 & 14 & 8 & 2 & 11 & 2 & 0 & 31 & 7 & 1 & 124 \\
\hline 5.90 & 1 & 0 & 2 & 20 & 28 & 16 & 12 & 8 & 18 & 5 & 0 & 0 & 71 & 8 & 3 & 108 \\
\hline 5.79 & 0 & 0 & 0 & 11 & 37 & 15 & 6 & 13 & 16 & 16 & 0 & 0 & 121 & 1 & 0 & 66 \\
\hline 5.67 & 0 & 0 & 1 & 12 & 29 & 17 & 4 & 6 & 11 & 4 & 0 & 0 & 129 & 0 & 0 & 94 \\
\hline 5.57 & 0 & 0 & 0 & 7 & 7 & 19 & 7 & 2 & 22 & 33 & 1 & 2 & 117 & 2 & 1 & 74 \\
\hline 5.49 & 0 & 0 & 0 & 13 & 3 & 17 & 6 & 0 & 27 & 27 & 3 & 0 & 149 & 0 & 0 & 56 \\
\hline 5.42 & 0 & 0 & 2 & 13 & 9 & 14 & 6 & 0 & 21 & 21 & 9 & 0 & 135 & 1 & 0 & 77 \\
\hline 5.35 & 0 & 1 & 0 & 8 & 6 & 16 & 4 & 0 & 15 & 5 & 3 & 0 & 167 & 0 & 2 & 74 \\
\hline 5.30 & 0 & 0 & 1 & 4 & 5 & 10 & 3 & 1 & 4 & 6 & 10 & 0 & 179 & 0 & 0 & 88 \\
\hline 5.25 & 0 & 0 & 0 & 3 & 1 & 4 & 3 & 2 & 3 & 8 & 1 & 0 & 220 & 0 & 11 & 46 \\
\hline 5.18 & 0 & 0 & 0 & 3 & 12 & 5 & 7 & 0 & 1 & 13 & 0 & 1 & 150 & 3 & 15 & 90 \\
\hline 5.09 & 0 & 0 & 0 & 4 & 149 & 17 & 5 & 0 & 0 & 21 & 0 & 1 & 6 & 2 & 1 & 96 \\
\hline 4.97 & 0 & 0 & 4 & 5 & 34 & 14 & 15 & 6 & 5 & 13 & 0 & 5 & 3 & 60 & 0 & 136 \\
\hline 4.84 & 0 & 0 & 19 & 45 & 44 & 7 & 26 & 7 & 4 & 2 & 0 & 2 & 3 & 9 & 1 & 132 \\
\hline 4.72 & 0 & 1 & 1 & 21 & 56 & 4 & 20 & 6 & 2 & 1 & 0 & 5 & 4 & 2 & 3 & 174 \\
\hline 4.57 & 0 & 0 & 11 & 16 & 86 & 36 & 17 & 2 & 3 & 8 & 0 & 5 & 1 & 2 & 0 & 113 \\
\hline 4.43 & 0 & 0 & 6 & 21 & 101 & 17 & 15 & 3 & 2 & 7 & 0 & 6 & 12 & 5 & 2 & 104 \\
\hline 4.33 & 0 & 9 & 3 & 47 & 114 & 7 & 13 & 0 & 1 & 13 & 0 & 1 & 6 & 6 & 3 & 79 \\
\hline 4.07 & 0 & 2 & 2 & 14 & 43 & 12 & 12 & 2 & 4 & 8 & 0 & 3 & 42 & 10 & 10 & 121 \\
\hline 3.95 & 1 & 3 & 10 & 24 & 82 & 21 & 16 & 7 & 0 & 9 & 0 & 1 & 6 & 5 & 2 & 113 \\
\hline 3.89 & 0 & 0 & 4 & 16 & 56 & 13 & 11 & 2 & 7 & 15 & 4 & 1 & 72 & 3 & 3 & 101 \\
\hline 3.87 & 0 & 1 & 13 & 37 & 20 & 11 & 19 & 17 & 0 & 6 & 1 & 1 & 9 & 6 & 4 & 156 \\
\hline 3.78 & 0 & 3 & 17 & 14 & 19 & 30 & 20 & 3 & 0 & 4 & 0 & 4 & 5 & 5 & 7 & 179 \\
\hline 3.64 & 0 & 1 & 5 & 11 & 62 & 35 & 14 & 8 & 0 & 5 & 0 & 2 & 11 & 4 & 7 & 149 \\
\hline 3.59 & 2 & 4 & 10 & 18 & 72 & 36 & 13 & 14 & 1 & 14 & 0 & 0 & 8 & 0 & 2 & 112 \\
\hline 3.38 & 0 & 3 & 14 & 27 & 28 & 72 & 18 & 12 & 1 & 5 & 0 & 1 & 9 & 3 & 3 & 106 \\
\hline 3.30 & 0 & 2 & 0 & 15 & 76 & 43 & 7 & 6 & 0 & 23 & 3 & 0 & 8 & 16 & 1 & 101 \\
\hline 3.14 & 5 & 2 & 11 & 12 & 49 & 34 & 12 & 10 & 0 & 9 & 3 & 0 & 11 & 4 & 2 & 136 \\
\hline 2.87 & 1 & 0 & 11 & 13 & 32 & 41 & 10 & 14 & 8 & 4 & 2 & 2 & 9 & 20 & 2 & 134 \\
\hline 2.73 & 1 & 1 & 0 & 12 & 54 & 33 & 18 & 21 & 9 & 7 & 1 & 0 & 17 & 3 & 2 & 141 \\
\hline 2.55 & 2 & 6 & 13 & 36 & 46 & 15 & 11 & 14 & 18 & 1 & 1 & 3 & 10 & 4 & 1 & 120 \\
\hline 2.38 & 0 & 2 & 18 & 15 & 73 & 40 & 3 & 11 & 0 & 19 & 0 & 4 & 4 & 9 & 2 & 99 \\
\hline 2.23 & 0 & 0 & 12 & 17 & 64 & 63 & 16 & 8 & 5 & 31 & 3 & 1 & 3 & 2 & 0 & 79 \\
\hline 2.14 & 1 & 0 & 11 & 25 & 57 & 30 & 19 & 11 & 4 & 11 & 0 & 0 & 2 & 3 & 1 & 136 \\
\hline 2.07 & 1 & 2 & 10 & 40 & 50 & 63 & 14 & 9 & 3 & 7 & 0 & 1 & 3 & 5 & 1 & 91 \\
\hline $\begin{array}{l}1.98 \\
\end{array}$ & 0 & 2 & 13 & 39 & 121 & 10 & 15 & 6 & 0 & 12 & 0 & 0 & 1 & 0 & 0 & 97 \\
\hline $\begin{array}{l}1.91 \\
\end{array}$ & 0 & 3 & 14 & 18 & 126 & 19 & 11 & 8 & 0 & 8 & 1 & 2 & 6 & 1 & 1 & 82 \\
\hline $\begin{array}{l}1.77 \\
\end{array}$ & 6 & 4 & 11 & 24 & 17 & 18 & 16 & 6 & 0 & 3 & 2 & 3 & 4 & 32 & 1 & 160 \\
\hline 1.61 & 0 & 0 & 2 & 20 & 65 & 51 & 18 & 3 & 0 & 16 & 4 & 0 & 4 & 23 & 1 & 94 \\
\hline 1.50 & 1 & 4 & 14 & 34 & 67 & 16 & 13 & 8 & 0 & 6 & 1 & 1 & 3 & 5 & 3 & 130 \\
\hline 1.31 & 0 & 7 & 7 & 22 & 74 & 31 & 12 & 13 & 0 & 8 & 1 & 1 & 3 & 0 & 0 & 123 \\
\hline 1.19 & 0 & 2 & 13 & 46 & 63 & 28 & 5 & 8 & 0 & 5 & 0 & 0 & 3 & 1 & 0 & 127 \\
\hline 1.09 & 6 & 4 & 37 & 31 & 31 & 40 & 12 & 8 & 0 & 3 & 0 & 0 & 6 & 1 & 0 & 121 \\
\hline 0.98 & 6 & 3 & 20 & 39 & 30 & 40 & 20 & 0 & 0 & 5 & 3 & 2 & 5 & 2 & 3 & 124 \\
\hline 0.85 & 3 & 1 & 8 & 71 & 30 & 47 & 12 & 1 & 0 & 6 & 0 & 2 & 1 & 1 & 0 & 118 \\
\hline 0.52 & 4 & 1 & 14 & 37 & 30 & 61 & 17 & 0 & 0 & 1 & 0 & 2 & 8 & 1 & 0 & 129 \\
\hline 0.45 & 11 & 3 & 14 & 37 & 35 & 36 & 6 & 0 & 1 & 1 & 1 & 2 & 6 & 0 & 0 & 147 \\
\hline 0.40 & 15 & 3 & 21 & 31 & 27 & 40 & 15 & 0 & 0 & 1 & 1 & 2 & 0 & 0 & 2 & 145 \\
\hline 0.36 & 5 & 1 & 19 & 49 & 13 & 46 & 6 & 1 & 0 & 4 & 3 & 1 & 3 & 0 & 0 & 159 \\
\hline 0.32 & 3 & 2 & 25 & 55 & 29 & 36 & 6 & 0 & 0 & 4 & 3 & 1 & 1 & 0 & 0 & 141 \\
\hline
\end{tabular}




\begin{tabular}{|c|c|c|c|c|c|c|c|c|c|c|c|c|c|c|c|c|}
\hline $\begin{array}{c}\mathrm{m} \\
\text { above } \\
\text { base } \\
\text { Main } \\
\text { Seam }\end{array}$ & 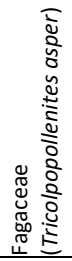 & 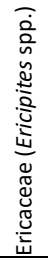 & 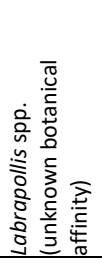 & 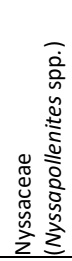 & 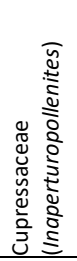 & 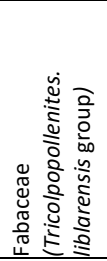 & 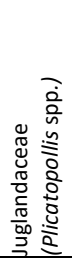 & 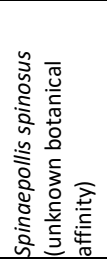 & 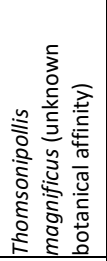 & 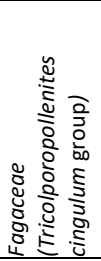 & 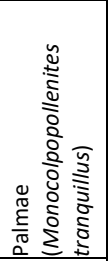 & 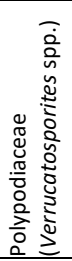 & 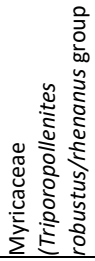 & 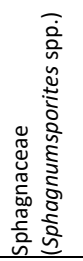 & 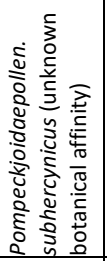 & 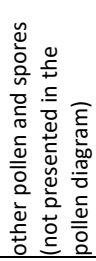 \\
\hline 0.28 & 1 & 3 & 14 & 62 & 61 & 20 & 8 & 0 & 0 & 6 & 1 & 2 & 3 & 0 & 0 & 119 \\
\hline 0.23 & 4 & 3 & 25 & 46 & 68 & 35 & 6 & 0 & 0 & 6 & 6 & 2 & 3 & 0 & 0 & 100 \\
\hline 0.18 & 0 & 1 & 4 & 4 & 47 & 6 & 0 & 0 & 1 & 5 & 1 & 0 & 69 & 0 & 2 & 60 \\
\hline 0.15 & 2 & 0 & 16 & 30 & 82 & 18 & 12 & 0 & 0 & 5 & 2 & 0 & 4 & 0 & 0 & 141 \\
\hline 0.12 & 3 & 0 & 25 & 40 & 35 & 26 & 11 & 0 & 0 & 3 & 0 & 2 & 1 & 0 & 0 & 156 \\
\hline 0.08 & 3 & 1 & 17 & 68 & 22 & 22 & 20 & 0 & 0 & 1 & 3 & 0 & 1 & 0 & 0 & 147 \\
\hline 0.03 & 15 & 0 & 13 & 63 & 10 & 24 & 20 & 0 & 0 & 1 & 8 & 0 & 2 & 0 & 1 & 143 \\
\hline
\end{tabular}


Tab. S3 Palynological data of the Main Seam (in \%).

\begin{tabular}{|c|c|c|c|c|c|c|c|c|c|c|c|c|c|c|c|c|}
\hline $\begin{array}{c}\mathrm{m} \\
\text { above } \\
\text { base } \\
\text { Main } \\
\text { Seam }\end{array}$ & 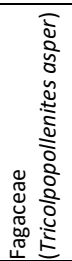 & 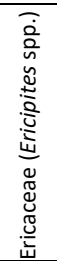 & 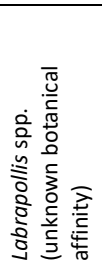 & 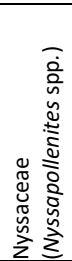 & 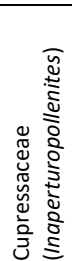 & 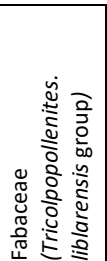 & 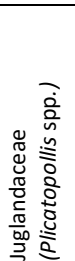 & 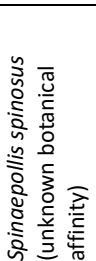 & 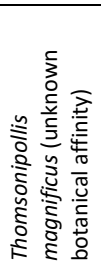 & 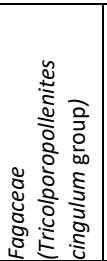 & 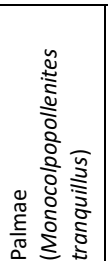 & 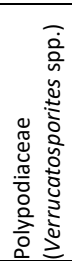 & 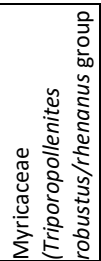 & 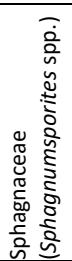 & 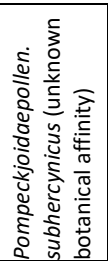 & 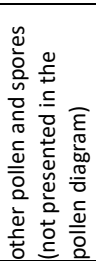 \\
\hline 11.05 & 0.0 & 0.0 & 0.6 & 2.0 & 3.2 & 16.7 & 3.2 & 0.0 & 3.4 & 1.4 & 1.6 & 0.2 & 9.6 & 0.2 & 10.2 & 47.6 \\
\hline 10.98 & 0.0 & 0.0 & 0.7 & 2.6 & 1.6 & 19.9 & 2.9 & 0.3 & 3.9 & 2.6 & 1.0 & 0.0 & 16.0 & 0.7 & 6.2 & 41.7 \\
\hline 10.87 & 0.0 & 0.0 & 0.0 & 6.3 & 7.3 & 1.0 & 3.0 & 0.3 & 0.0 & 0.7 & 0.0 & 0.7 & 32.7 & 7.0 & 11.3 & 29.7 \\
\hline 10.78 & 0.0 & 0.0 & 0.7 & 7.3 & 14.6 & 2.3 & 5.3 & 0.0 & 0.0 & 0.3 & 0.0 & 1.0 & 15.6 & 0.7 & 13.9 & 38.4 \\
\hline 10.70 & 0.0 & 0.0 & 0.7 & 5.3 & 10.0 & 4.0 & 2.0 & 1.0 & 0.0 & 1.3 & 2.0 & 1.0 & 14.3 & 1.0 & 13.3 & 44.0 \\
\hline 10.59 & 1.0 & 0.0 & 0.0 & 5.0 & 3.7 & 4.3 & 2.0 & 3.3 & 0.3 & 0.7 & 6.0 & 2.7 & 34.1 & 0.0 & 1.3 & 35.5 \\
\hline 10.50 & 0.0 & 0.0 & 0.3 & 1.0 & 5.3 & 2.7 & 2.7 & 0.0 & 0.0 & 1.3 & 1.7 & 0.0 & 33.2 & 3.7 & 6.0 & 42.2 \\
\hline 10.34 & 0.0 & 0.0 & 0.0 & 1.0 & 2.0 & 4.0 & 1.3 & 0.0 & 0.0 & 1.0 & 2.0 & 1.3 & 44.7 & 4.7 & 2.7 & 35.3 \\
\hline 10.21 & 0.0 & 0.0 & 1.6 & 2.3 & 7.5 & 3.9 & 3.9 & 0.0 & 0.7 & 4.9 & 0.0 & 7.5 & 11.1 & 8.2 & 1.3 & 47.1 \\
\hline 10.11 & 0.0 & 1.0 & 0.7 & 4.0 & 14.5 & 1.3 & 2.3 & 0.7 & 2.3 & 2.3 & 1.3 & 1.3 & 16.2 & 2.6 & 15.8 & 33.7 \\
\hline 9.52 & 0.0 & 0.3 & 0.7 & 3.0 & 17.7 & 4.3 & 2.7 & 0.0 & 2.3 & 4.3 & 0.3 & 0.7 & 17.0 & 0.0 & 21.3 & 25.3 \\
\hline 9.41 & 0.0 & 0.0 & 0.7 & 2.3 & 23.5 & 4.0 & 5.0 & 0.7 & 0.3 & 2.6 & 0.3 & 1.0 & 14.6 & 0.7 & 13.2 & 31.1 \\
\hline 9.32 & 0.0 & 0.0 & 0.0 & 2.0 & 7.0 & 2.0 & 0.7 & 0.0 & 0.7 & 1.0 & 0.3 & 0.3 & 0.3 & 9.0 & 8.0 & 68.7 \\
\hline 9.19 & 0.0 & 0.0 & 0.0 & 1.0 & 2.6 & 4.3 & 2.0 & 0.0 & 0.0 & 1.3 & 0.0 & 0.0 & 2.0 & 4.6 & 52.5 & 29.8 \\
\hline 9.06 & 0.0 & 0.0 & 0.3 & 0.6 & 3.5 & 2.2 & 1.3 & 0.3 & 0.0 & 2.2 & 0.0 & 0.0 & 6.1 & 23.4 & 31.1 & 28.8 \\
\hline 8.90 & 0.0 & 0.0 & 0.3 & 0.0 & 1.0 & 0.3 & 1.3 & 0.0 & 0.0 & 0.3 & 0.0 & 0.7 & 7.3 & 6.3 & 57.3 & 25.0 \\
\hline 8.77 & 0.7 & 0.3 & 1.0 & 2.0 & 1.0 & 3.7 & 0.7 & 0.0 & 0.3 & 0.0 & 0.3 & 0.0 & 15.7 & 3.0 & 52.3 & 19.0 \\
\hline 8.67 & 0.3 & 0.0 & 0.0 & 1.0 & 7.4 & 1.9 & 2.3 & 0.0 & 0.0 & 3.9 & 0.3 & 0.0 & 9.6 & 9.6 & 20.9 & 42.8 \\
\hline 8.37 & 0.0 & 0.0 & 0.0 & 0.7 & 4.3 & 1.7 & 3.3 & 0.0 & 0.0 & 4.7 & 0.0 & 0.0 & 19.6 & 11.0 & 36.2 & 18.6 \\
\hline 8.23 & 0.0 & 0.0 & 0.0 & 1.0 & 5.7 & 3.0 & 2.0 & 0.0 & 0.0 & 4.3 & 0.0 & 0.0 & 16.3 & 5.7 & 41.0 & 21.0 \\
\hline 8.13 & 0.0 & 0.3 & 1.0 & 0.3 & 1.7 & 4.0 & 0.7 & 0.3 & 0.0 & 1.0 & 0.3 & 0.0 & 23.0 & 37.3 & 12.7 & 17.3 \\
\hline 7.98 & 0.0 & 0.0 & 3.0 & 3.3 & 11.7 & 10.0 & 4.7 & 0.7 & 0.3 & 4.0 & 0.7 & 0.3 & 8.3 & 19.3 & 10.3 & 23.3 \\
\hline 7.86 & 0.3 & 0.0 & 2.3 & 2.7 & 32.0 & 15.7 & 4.3 & 2.3 & 0.3 & 3.7 & 0.0 & 0.3 & 1.7 & 0.7 & 0.7 & 33.0 \\
\hline 7.82 & 0.0 & 0.0 & 2.3 & 2.7 & 41.0 & 5.7 & 4.0 & 2.3 & 0.0 & 5.0 & 0.3 & 1.0 & 0.0 & 0.3 & 0.7 & 34.7 \\
\hline 7.77 & 0.3 & 0.0 & 4.3 & 6.3 & 19.7 & 17.0 & 7.3 & 3.7 & 0.0 & 3.3 & 0.0 & 0.7 & 1.0 & 0.7 & 0.3 & 35.3 \\
\hline 7.73 & 0.3 & 0.0 & 4.0 & 4.0 & 7.9 & 11.9 & 5.6 & 3.0 & 1.0 & 3.0 & 1.0 & 1.3 & 2.3 & 0.0 & 0.3 & 54.5 \\
\hline 7.70 & 0.9 & 0.0 & 3.8 & 6.3 & 14.7 & 10.6 & 9.1 & 2.8 & 0.0 & 2.5 & 0.9 & 1.6 & 2.5 & 0.6 & 0.6 & 43.1 \\
\hline 7.62 & 0.0 & 0.0 & 3.3 & 16.3 & 15.3 & 6.8 & 4.6 & 1.0 & 1.6 & 7.8 & 0.3 & 0.7 & 3.6 & 0.7 & 0.3 & 37.8 \\
\hline 7.52 & 0.3 & 0.3 & 2.3 & 5.0 & 4.0 & $\begin{array}{l}11.3 \\
\end{array}$ & 2.0 & 2.0 & 0.7 & 0.3 & 0.0 & 0.3 & 13.3 & 0.7 & 3.7 & 53.8 \\
\hline 7.39 & 0.3 & 0.0 & 0.3 & 2.6 & 5.6 & 17.5 & 5.0 & 1.3 & 0.0 & 0.3 & 0.3 & 0.0 & 3.3 & 0.7 & 0.7 & 61.9 \\
\hline 7.34 & 0.0 & 0.0 & 0.3 & 2.7 & 1.0 & 22.7 & 3.0 & 3.7 & 0.0 & 32.0 & 0.0 & 0.0 & 8.7 & 1.0 & 1.3 & 23.7 \\
\hline 7.31 & 0.3 & 0.0 & 0.7 & 5.0 & 7.0 & 9.3 & 3.7 & 3.7 & 0.0 & 15.3 & 1.0 & 0.7 & 14.3 & 3.7 & 0.7 & 34.9 \\
\hline 7.25 & 0.0 & 0.0 & 0.3 & 6.0 & 9.6 & 15.0 & 3.0 & 2.3 & 1.3 & 15.9 & 0.0 & 0.7 & 15.0 & 0.0 & 0.3 & 30.6 \\
\hline 7.19 & 0.0 & 0.0 & 0.0 & 9.8 & 14.1 & 7.2 & 4.9 & 6.6 & 1.0 & 9.5 & 1.3 & 0.0 & 12.5 & 0.0 & 0.0 & 33.1 \\
\hline 7.15 & 0.0 & 0.0 & 0.3 & 6.3 & 13.3 & 24.6 & 3.0 & 2.3 & 0.7 & 14.3 & 0.3 & 0.0 & 3.3 & 0.0 & 0.0 & 31.6 \\
\hline 7.09 & 0.7 & 0.3 & 0.3 & 12.1 & 5.9 & 33.7 & 2.3 & 2.3 & 1.0 & 1.3 & 2.6 & 0.3 & 3.9 & 0.3 & 0.0 & 33.0 \\
\hline 6.98 & 0.0 & 0.3 & 0.0 & 7.2 & 8.5 & 13.1 & 3.0 & 1.0 & 0.0 & 18.7 & 7.5 & 0.3 & 2.0 & 0.0 & 0.0 & 38.4 \\
\hline 6.88 & 0.0 & 0.3 & 0.3 & 6.1 & 8.0 & 12.7 & 3.0 & 0.3 & 2.5 & 4.7 & 6.1 & 0.0 & 17.2 & 0.0 & 0.0 & 38.8 \\
\hline 6.76 & 0.0 & 0.0 & 0.0 & 0.3 & 6.6 & 1.3 & 3.0 & 0.0 & 0.7 & 3.3 & 0.7 & 0.0 & 65.8 & 0.0 & 0.0 & 18.3 \\
\hline 6.66 & 0.0 & 0.3 & 0.3 & 10.4 & 5.5 & 12.6 & 2.6 & 1.3 & 2.3 & 13.9 & 1.3 & 0.3 & 23.3 & 0.3 & 0.0 & 25.6 \\
\hline 6.58 & 0.0 & 0.0 & 0.0 & 11.6 & 15.3 & 11.6 & 1.3 & 1.3 & 3.3 & 15.3 & 1.3 & 0.0 & 5.3 & 0.0 & 0.3 & 33.2 \\
\hline 6.47 & 0.0 & 0.0 & 1.0 & 0.7 & 3.6 & 3.6 & 1.7 & 0.0 & 0.0 & 1.0 & 1.3 & 0.0 & 32.8 & 1.0 & 0.3 & 53.0 \\
\hline 6.34 & 0.0 & 0.3 & 0.0 & 7.3 & 20.9 & 6.0 & 6.6 & 4.3 & 8.3 & 8.3 & 0.7 & 0.0 & 5.0 & 0.7 & 0.3 & 31.5 \\
\hline 6.29 & 0.0 & 0.0 & 0.7 & 9.7 & 15.0 & 9.0 & 1.3 & 8.3 & 7.7 & 3.0 & 0.7 & 1.3 & 1.3 & 1.0 & 1.0 & 40.0 \\
\hline 6.26 & 0.0 & 0.3 & 0.0 & 7.2 & 37.4 & 5.2 & 3.3 & 3.3 & 5.6 & 4.3 & 0.0 & 0.7 & 7.9 & 0.0 & 0.0 & 24.9 \\
\hline 6.21 & 0.0 & 0.0 & 0.3 & 5.3 & 27.7 & 5.7 & 2.0 & 7.7 & 4.0 & 4.0 & 2.3 & 0.0 & 13.3 & 0.0 & 0.0 & 27.7 \\
\hline 6.15 & 0.0 & 0.0 & 0.0 & 4.3 & 40.0 & 5.0 & 2.0 & 1.0 & 2.3 & 10.3 & 0.7 & 0.0 & 11.7 & 0.0 & 0.0 & 22.7 \\
\hline 6.09 & 0.0 & 0.0 & 0.0 & 3.3 & 22.3 & 4.0 & 2.7 & 1.0 & 0.7 & 3.7 & 2.0 & 0.0 & 41.9 & 0.3 & 0.0 & 18.3 \\
\hline
\end{tabular}




\begin{tabular}{|c|c|c|c|c|c|c|c|c|c|c|c|c|c|c|c|c|}
\hline $\begin{array}{c}\mathrm{m} \\
\text { above } \\
\text { base } \\
\text { Main } \\
\text { Seam }\end{array}$ & 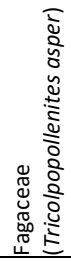 & 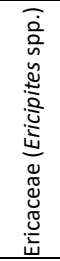 & 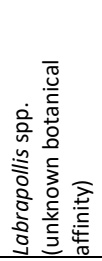 & 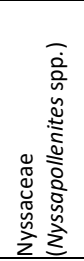 & 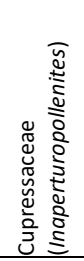 & 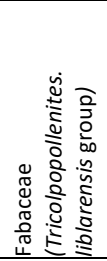 & 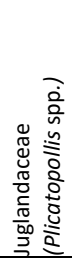 & 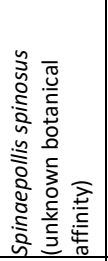 & 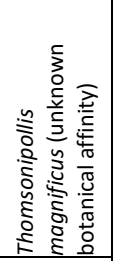 & 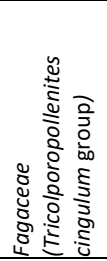 & 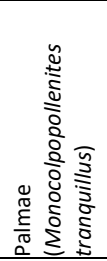 & 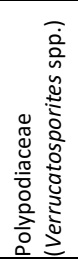 & 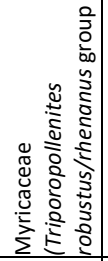 & 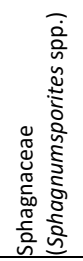 & 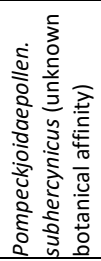 & 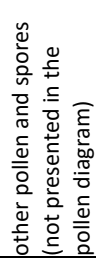 \\
\hline 5.99 & 0.7 & 0.0 & 1.7 & 2.3 & 13.0 & 15.4 & 4.7 & 2.7 & 0.7 & 3.7 & 0.7 & 0.0 & 10.4 & 2.3 & 0.3 & 41.5 \\
\hline 5.90 & 0.3 & 0.0 & 0.7 & 6.7 & 9.3 & 5.3 & 4.0 & 2.7 & 6.0 & 1.7 & 0.0 & 0.0 & 23.7 & 2.7 & 1.0 & 36.0 \\
\hline 5.79 & 0.0 & 0.0 & 0.0 & 3.6 & 12.3 & 5.0 & 2.0 & 4.3 & 5.3 & 5.3 & 0.0 & 0.0 & 40.1 & 0.3 & 0.0 & 21.9 \\
\hline 5.67 & 0.0 & 0.0 & 0.3 & 3.9 & 9.4 & 5.5 & 1.3 & 2.0 & 3.6 & 1.3 & 0.0 & 0.0 & 42.0 & 0.0 & 0.0 & 30.6 \\
\hline 5.57 & 0.0 & 0.0 & 0.0 & 2.4 & 2.4 & 6.5 & 2.4 & 0.7 & 7.5 & 11.2 & 0.3 & 0.7 & 39.8 & 0.7 & 0.3 & 25.2 \\
\hline 5.49 & 0.0 & 0.0 & 0.0 & 4.3 & 1.0 & 5.6 & 2.0 & 0.0 & 9.0 & 9.0 & 1.0 & 0.0 & 49.5 & 0.0 & 0.0 & 18.6 \\
\hline 5.42 & 0.0 & 0.0 & 0.6 & 4.2 & 2.9 & 4.5 & 1.9 & 0.0 & 6.8 & 6.8 & 2.9 & 0.0 & 43.8 & 0.3 & 0.0 & 25.0 \\
\hline 5.35 & 0.0 & 0.3 & 0.0 & 2.7 & 2.0 & 5.3 & 1.3 & 0.0 & 5.0 & 1.7 & 1.0 & 0.0 & 55.5 & 0.0 & 0.7 & 24.6 \\
\hline 5.30 & 0.0 & 0.0 & 0.3 & 1.3 & 1.6 & 3.2 & 1.0 & 0.3 & 1.3 & 1.9 & 3.2 & 0.0 & 57.6 & 0.0 & 0.0 & 28.3 \\
\hline 5.25 & 0.0 & 0.0 & 0.0 & 1.0 & 0.3 & 1.3 & 1.0 & 0.7 & 1.0 & 2.6 & 0.3 & 0.0 & 72.8 & 0.0 & 3.6 & 15.2 \\
\hline 5.18 & 0.0 & 0.0 & 0.0 & 1.0 & 4.0 & 1.7 & 2.3 & 0.0 & 0.3 & 4.3 & 0.0 & 0.3 & 50.0 & 1.0 & 5.0 & 30.0 \\
\hline 5.09 & 0.0 & 0.0 & 0.0 & 1.3 & 49.3 & 5.6 & 1.7 & 0.0 & 0.0 & 7.0 & 0.0 & 0.3 & 2.0 & 0.7 & 0.3 & 31.8 \\
\hline 4.97 & 0.0 & 0.0 & 1.3 & 1.7 & 11.3 & 4.7 & 5.0 & 2.0 & 1.7 & 4.3 & 0.0 & 1.7 & 1.0 & 20.0 & 0.0 & 45.3 \\
\hline 4.84 & 0.0 & 0.0 & 6.3 & 15.0 & 14.6 & 2.3 & 8.6 & 2.3 & 1.3 & 0.7 & 0.0 & 0.7 & 1.0 & 3.0 & 0.3 & 43.9 \\
\hline 4.72 & 0.0 & 0.3 & 0.3 & 7.0 & 18.7 & 1.3 & 6.7 & 2.0 & 0.7 & 0.3 & 0.0 & 1.7 & 1.3 & 0.7 & 1.0 & 58.0 \\
\hline 4.57 & 0.0 & 0.0 & 3.7 & 5.3 & 28.7 & 12.0 & 5.7 & 0.7 & 1.0 & 2.7 & 0.0 & 1.7 & 0.3 & 0.7 & 0.0 & 37.7 \\
\hline 4.43 & 0.0 & 0.0 & 2.0 & 7.0 & 33.6 & 5.6 & 5.0 & 1.0 & 0.7 & 2.3 & 0.0 & 2.0 & 4.0 & 1.7 & 0.7 & 34.6 \\
\hline 4.33 & 0.0 & 3.0 & 1.0 & 15.6 & 37.7 & 2.3 & 4.3 & 0.0 & 0.3 & 4.3 & 0.0 & 0.3 & 2.0 & 2.0 & 1.0 & 26.2 \\
\hline 4.07 & 0.0 & 0.7 & 0.7 & 4.9 & 15.1 & 4.2 & 4.2 & 0.7 & 1.4 & 2.8 & 0.0 & 1.1 & 14.7 & 3.5 & 3.5 & 42.5 \\
\hline 3.95 & 0.3 & 1.0 & 3.3 & 8.0 & 27.3 & 7.0 & 5.3 & 2.3 & 0.0 & 3.0 & 0.0 & 0.3 & 2.0 & 1.7 & 0.7 & 37.7 \\
\hline 3.89 & 0.0 & 0.0 & 1.3 & 5.2 & 18.2 & 4.2 & 3.6 & 0.6 & 2.3 & 4.9 & 1.3 & 0.3 & 23.4 & 1.0 & 1.0 & 32.8 \\
\hline 3.87 & 0.0 & 0.3 & 4.3 & 12.3 & 6.6 & 3.7 & 6.3 & 5.6 & 0.0 & 2.0 & 0.3 & 0.3 & 3.0 & 2.0 & 1.3 & 51.8 \\
\hline 3.78 & 0.0 & 1.0 & 5.5 & 4.5 & 6.1 & 9.7 & 6.5 & 1.0 & 0.0 & 1.3 & 0.0 & 1.3 & 1.6 & 1.6 & 2.3 & 57.7 \\
\hline 3.64 & 0.0 & 0.3 & 1.6 & 3.5 & 19.7 & 11.1 & 4.5 & 2.5 & 0.0 & 1.6 & 0.0 & 0.6 & 3.5 & 1.3 & 2.2 & 47.5 \\
\hline 3.59 & 0.7 & 1.3 & 3.3 & 5.9 & 23.5 & 11.8 & 4.2 & 4.6 & 0.3 & 4.6 & 0.0 & 0.0 & 2.6 & 0.0 & 0.7 & 36.6 \\
\hline 3.38 & 0.0 & 1.0 & 4.6 & 8.9 & 9.3 & 23.8 & 6.0 & 4.0 & 0.3 & 1.7 & 0.0 & 0.3 & 3.0 & 1.0 & 1.0 & 35.1 \\
\hline 3.30 & 0.0 & 0.7 & 0.0 & 5.0 & 25.2 & 14.3 & 2.3 & 2.0 & 0.0 & 7.6 & 1.0 & 0.0 & 2.7 & 5.3 & 0.3 & 33.6 \\
\hline 3.14 & 1.7 & 0.7 & 3.7 & 4.0 & 16.3 & 11.3 & 4.0 & 3.3 & 0.0 & 3.0 & 1.0 & 0.0 & 3.7 & 1.3 & 0.7 & 45.3 \\
\hline 2.87 & 0.3 & 0.0 & 3.6 & 4.3 & 10.6 & 13.5 & 3.3 & 4.6 & 2.6 & 1.3 & 0.7 & 0.7 & 3.0 & 6.6 & 0.7 & 44.2 \\
\hline 2.73 & 0.3 & 0.3 & 0.0 & 3.8 & 16.9 & 10.3 & 5.6 & 6.6 & 2.8 & 2.2 & 0.3 & 0.0 & 5.3 & 0.9 & 0.6 & 44.1 \\
\hline 2.55 & 0.7 & 2.0 & 4.3 & 12.0 & 15.3 & 5.0 & 3.7 & 4.7 & 6.0 & 0.3 & 0.3 & 1.0 & 3.3 & 1.3 & 0.3 & 39.9 \\
\hline 2.38 & 0.0 & 0.7 & 6.0 & 5.0 & 24.4 & 13.4 & 1.0 & 3.7 & 0.0 & 6.4 & 0.0 & 1.3 & 1.3 & 3.0 & 0.7 & 33.1 \\
\hline 2.23 & 0.0 & 0.0 & 3.9 & 5.6 & 21.1 & 20.7 & 5.3 & 2.6 & 1.6 & 10.2 & 1.0 & 0.3 & 1.0 & 0.7 & 0.0 & 26.0 \\
\hline 2.14 & 0.3 & 0.0 & 3.5 & 8.0 & 18.3 & 9.6 & 6.1 & 3.5 & 1.3 & 3.5 & 0.0 & 0.0 & 0.6 & 1.0 & 0.3 & 43.7 \\
\hline 2.07 & 0.3 & 0.7 & 3.3 & 13.3 & 16.7 & 21.0 & 4.7 & 3.0 & 1.0 & 2.3 & 0.0 & 0.3 & 1.0 & 1.7 & 0.3 & 30.3 \\
\hline 1.98 & 0.0 & 0.6 & 4.1 & 12.3 & 38.3 & 3.2 & 4.7 & 1.9 & 0.0 & 3.8 & 0.0 & 0.0 & 0.3 & 0.0 & 0.0 & 30.7 \\
\hline 1.91 & 0.0 & 1.0 & 4.7 & 6.0 & 42.0 & 6.3 & 3.7 & 2.7 & 0.0 & 2.7 & 0.3 & 0.7 & 2.0 & 0.3 & 0.3 & 27.3 \\
\hline 1.77 & 2.0 & 1.3 & 3.6 & 7.8 & 5.5 & 5.9 & 5.2 & 2.0 & 0.0 & 1.0 & 0.7 & 1.0 & 1.3 & 10.4 & 0.3 & 52.1 \\
\hline 1.61 & 0.0 & 0.0 & 0.7 & 6.6 & 21.6 & 16.9 & 6.0 & 1.0 & 0.0 & 5.3 & 1.3 & 0.0 & 1.3 & 7.6 & 0.3 & 31.2 \\
\hline 1.50 & 0.3 & 1.3 & 4.6 & 11.1 & 21.9 & 5.2 & 4.2 & 2.6 & 0.0 & 2.0 & 0.3 & 0.3 & 1.0 & 1.6 & 1.0 & 42.5 \\
\hline 1.31 & 0.0 & 2.3 & 2.3 & 7.3 & 24.5 & 10.3 & 4.0 & 4.3 & 0.0 & 2.6 & 0.3 & 0.3 & 1.0 & 0.0 & 0.0 & 40.7 \\
\hline 1.19 & 0.0 & 0.7 & 4.3 & 15.3 & 20.9 & 9.3 & 1.7 & 2.7 & 0.0 & 1.7 & 0.0 & 0.0 & 1.0 & 0.3 & 0.0 & 42.2 \\
\hline 1.09 & 2.0 & 1.3 & 12.3 & 10.3 & 10.3 & 13.3 & 4.0 & 2.7 & 0.0 & 1.0 & 0.0 & 0.0 & 2.0 & 0.3 & 0.0 & 40.3 \\
\hline 0.98 & 2.0 & 1.0 & 6.6 & 12.9 & 9.9 & 13.2 & 6.6 & 0.0 & 0.0 & 1.7 & 1.0 & 0.7 & 1.7 & 0.7 & 1.0 & 41.1 \\
\hline 0.85 & 1.0 & 0.3 & 2.7 & 23.6 & 10.0 & 15.6 & 4.0 & 0.3 & 0.0 & 2.0 & 0.0 & 0.7 & 0.3 & 0.3 & 0.0 & 39.2 \\
\hline 0.52 & 1.3 & 0.3 & 4.6 & 12.1 & 9.8 & 20.0 & 5.6 & 0.0 & 0.0 & 0.3 & 0.0 & 0.7 & 2.6 & 0.3 & 0.0 & 42.3 \\
\hline 0.45 & 3.7 & 1.0 & 4.7 & 12.3 & 11.7 & 12.0 & 2.0 & 0.0 & 0.3 & 0.3 & 0.3 & 0.7 & 2.0 & 0.0 & 0.0 & 49.0 \\
\hline 0.40 & 5.0 & 1.0 & 6.9 & 10.2 & 8.9 & 13.2 & 5.0 & 0.0 & 0.0 & 0.3 & 0.3 & 0.7 & 0.0 & 0.0 & 0.7 & 47.9 \\
\hline 0.36 & 1.6 & 0.3 & 6.1 & 15.8 & 4.2 & 14.8 & 1.9 & 0.3 & 0.0 & 1.3 & 1.0 & 0.3 & 1.0 & 0.0 & 0.0 & 51.3 \\
\hline 0.32 & 1.0 & 0.7 & 8.2 & 18.0 & 9.5 & 11.8 & 2.0 & 0.0 & 0.0 & 1.3 & 1.0 & 0.3 & 0.3 & 0.0 & 0.0 & 46.1 \\
\hline
\end{tabular}




\begin{tabular}{|c|c|c|c|c|c|c|c|c|c|c|c|c|c|c|c|c|}
\hline $\begin{array}{c}\mathrm{m} \\
\text { above } \\
\text { base } \\
\text { Main } \\
\text { Seam }\end{array}$ & 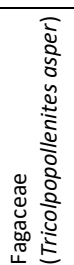 & 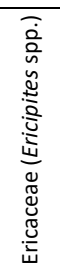 & 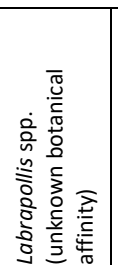 & 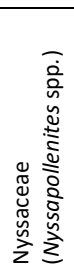 & 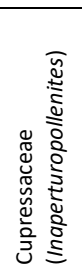 & 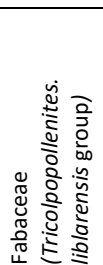 & 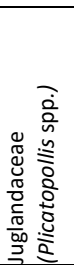 & 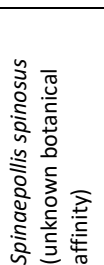 & 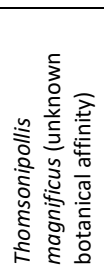 & 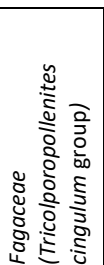 & 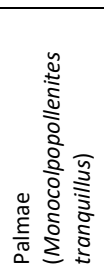 & 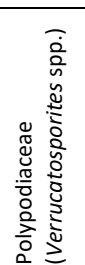 & 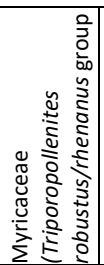 & 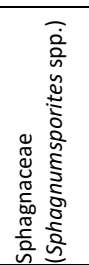 & 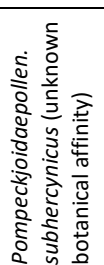 & 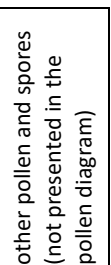 \\
\hline 0.28 & 0.3 & 1.0 & 4.7 & 20.7 & 20.3 & 6.7 & 2.7 & 0.0 & 0.0 & 2.0 & 0.3 & 0.7 & 1.0 & 0.0 & 0.0 & 39.7 \\
\hline 0.23 & 1.3 & 1.0 & 8.2 & $\begin{array}{ll}15.1 \\
\end{array}$ & 22.4 & 11.5 & 2.0 & 0.0 & 0.0 & 2.0 & 2.0 & 0.7 & 1.0 & 0.0 & 0.0 & 32.9 \\
\hline $\begin{array}{ll}0.18 \\
\end{array}$ & $\begin{array}{l}0.0 \\
\end{array}$ & 0.5 & 2.0 & 2.0 & 23.5 & 3.0 & 0.0 & 0.0 & 0.5 & 2.5 & 0.5 & 0 & 34.5 & 0.0 & 1.0 & 30.0 \\
\hline $\begin{array}{l}0.15 \\
\end{array}$ & $\begin{array}{l}0.6 \\
\end{array}$ & 0.0 & 5.1 & $\begin{array}{l}9.6 \\
\end{array}$ & 26.3 & 5.8 & 3.8 & 0.0 & $\begin{array}{l}0.0 \\
\end{array}$ & 1.6 & 0.6 & $\begin{array}{l}0.0 \\
\end{array}$ & 1.3 & 0.0 & 0.0 & 45.2 \\
\hline 0.12 & 1.0 & 0.0 & 8.3 & 13.2 & 11.6 & 8.6 & 3.6 & 0.0 & 0.0 & 1.0 & 0.0 & 0.7 & 0.3 & 0.0 & 0.0 & 51.7 \\
\hline $\begin{array}{ll}0.08 \\
\end{array}$ & 1.0 & 0.3 & 5.6 & 22.3 & 7.2 & 7.2 & 6.6 & 0.0 & 0.0 & 0.3 & 1.0 & 0.0 & 0.3 & 0.0 & 0.0 & 48.2 \\
\hline 0.03 & 5.0 & 0.0 & 4.3 & 21.0 & 3.3 & 8.0 & 6.7 & 0.0 & 0.0 & 0.3 & 2.7 & 0.0 & 0.7 & 0.0 & 0.3 & 47.7 \\
\hline
\end{tabular}

\section{References}

Baczynski, A. A., McInerney, F. A., Wing, S. L., Kraus, M. J., Bloch, J. I., Boyer, D. M., Secord, R., Morse, P. E., and Fricke, H. C.: Chemostratigraphic implications of spatial variation in the Paleocene-Eocene Thermal Maximum carbon isotope excursion, SE Bighorn Basin, Wyoming, Geochem. Geophys. Geosyst., 14, 41334152, https://doi.org/10.1002/ggge.20265, 2013.

Bataille, C. P., Mastalerz, M., Tipple, B. J., and Bowen, G. J.: Influence of provenance and preservation on the carbon isotope variations of dispersed organic matter in ancient floodplain sediments, Geochem. Geophys. Geosyst., 14, 4874-4891, https://doi.org/10.1002/ggge.20294, 2013.

Chen, Z., Wang, X., Hu, J., Yang, S., Zhu, M., Dong, X., Tang, Z., Peng, P., and Ding, Z.: Structure of the carbon isotope excursion in a high-resolution lacustrine Paleocene-Eocene Thermal Maximum record from central China. Earth Planet. Sc. Lett., 408, 331-340, https://doi.org/10.1016/j.eps1.2014.10.027, 2014.

Foreman, B. Z., Heller, P. L., and Clementz, M. T.: Fluvial response to abrupt global warming at the Palaeocene/Eocene boundary, Nature, 491, 92-95, 2012.

Jaramillo, C., Ochoa, D., Contreras, L., Pagani, M., Carvajal-Ortiz, H., Pratt, L. M., Krishnan, S., Cardona, A., Romero, M., Quiroz, L., Rodriguez, G., Rueda, M. J., de la Parra, F., Morón, S., Green, W., Bayona, G., Montes, C., Quintero, O., Ramirez, R., Mora, G., Schouten, S., Bermudez, H., Navarewtte, R., Parra, F., Alvarán, M., Osorno, J., Crowley, J. L., Valencia, V., and Vervoort, J.: Effects of rapid global warming at the Paleocene-Eocene Boundary on Neotropical Vegetation, Science, 330, 957-961, https://doi.org/10.1126/science.1193833, 2010.

Scotese, C. R.: Atlas of Paleogene Paleogeographic Maps (Mollweide Projection), Maps 8-15, Volume 1, The Cenozoic, PALEOMAP Atlas for ArcGIS, PALEOMAP Project, Evanston, IL, USA, 2014.

Storme, J. Y., Dupuis, C., Schnyder, J., Quesnel, F., Garel, S., Iakovleva, A. I., Iacumin, P., Di Matteo, A., Sebilo, M., and Yans, J.: Cycles of humid-dry climate conditions around the P/E boundary: new stable isotope data from terrestrial organic matter in Vasterival section (NW France), Terra Nova, 24, 114-122, https://doi.org/10.1111/j.1365-3121.2011.01044.x, 2012.

Vogt, W., 1981. Makropetrographischer Flözaufbau der rheinischen Braunkohle und Brikettiereigenschaften der Lithotypen. Fortschritte Geologie Rheinland Westfalen 29:449-468. 